NBER WORKING PAPER SERIES

\title{
DEFINED CONTRIBUTION PENSIONS: \\ PLAN RULES, PARTICIPANT DECISIONS, AND THE PATH OF LEAST RESISTANCE
}

\author{
James J. Choi \\ David Laibson \\ Brigitte C. Madrian \\ Andrew Metrick \\ Working Paper 8655 \\ http://www.nber.org/papers/w8655 \\ NATIONAL BUREAU OF ECONOMIC RESEARCH \\ 1050 Massachusetts Avenue \\ Cambridge, MA 02138 \\ December 2001
}

We thank Hewitt Associates for their help in providing the data. We are particularly grateful to Lori Lucas and Jim McGhee, two of our many contacts at Hewitt. We also thank James Poterba and Olivia Mitchell for comments. Choi acknowledges financial support from a National Science Foundation Graduate Research Fellowship. Laibson and Madrian acknowledge financial support from the National Institute on Aging (R01AG-16605 and R29-AG-013020 respectively). Laibson also acknowledges financial support from the MacArthur Foundation and the Sloan Foundation. The views expressed herein are those of the authors and not necessarily those of the National Bureau of Economic Research.

(C) 2001 by James J. Choi, David Laibson, Brigitte C. Madrian and Andrew Metrick. All rights reserved. Short sections of text, not to exceed two paragraphs, may be quoted without explicit permission provided that full credit, including (C) notice, is given to the source. 
Defined Contribution Pensions: Plan Rules, Participant Decisions, and the Path of Least Resistance James J. Choi, David Laibson, Brigitte C. Madrian and Andrew Metrick NBER Working Paper No. 8655

December 2001

JEL No. J320, H550, G110, D910

\begin{abstract}
We assess the impact on savings behavior of several different 401(k) plan features, including automatic enrollment, automatic cash distributions, employer matching provisions, eligibility requirements, investment options, and financial education. We also present new survey evidence on individual savings adequacy. Many of our conclusions are based on an analysis of micro-level administrative data on the 401(k) savings behavior of employees in several large corporations that implemented changes in their 401(k) plan design. Our analysis identifies a key behavioral principle that should partially guide the design of 401(k) plans: employees often follow "the path of least resistance." For better or for worse, plan administrators can manipulate the path of least resistance to powerfully influence the savings and investment choices of their employees.
\end{abstract}

James J. Choi

Department of Economics

Harvard University

Littauer Center

Cambridge, MA 02138

james_choi@post.harvard.edu

Brigitte C. Madrian

University of Chicago

Graduate School of Business

1101 E. 58th Street

Chicago, IL 60637

and NBER

brigitte.madrian@gsb.uchicago.edu
David Laibson

Department of Economics

Harvard University

Littauer Center

Cambridge, MA 02138

and NBER

dlaibson@harvard.edu

Andrew Metrick

Department of Finance, 2300 SH-DH

University of Pennsylvania, Wharton School

3620 Locust Walk

Philadelphia, PA 19104

and NBER

metrick@wharton.upenn.edu 


\section{Defined Contribution Pensions: Plan Rules, Participant Choices, and the Path of Least Resistance}

\section{Introduction}

Over the last 20 years, defined contribution pension plans have gradually replaced defined benefit pension plans as the primary privately-sponsored vehicle to provide retirement income. At year-end 2000, employers sponsored over 325,000 401(k) plans with more than 42 million active participants and $\$ 1.8$ trillion in assets. ${ }^{1}$

The growth of 401(k)-type savings plans and the associated displacement of defined benefit plans have generated new concerns about the adequacy of employee savings. Defined contribution pension plans place the burden of ensuring adequate retirement savings squarely on the backs of individual employees. However, employers make many decisions about the design of 401(k) plans that can either facilitate or hinder their employees' retirement savings prospects. Although the government places some limits on how companies can structure their 401(k) plans, employers nonetheless have broad discretion in the design of their 401(k) plans.

Making good plan design decisions requires an understanding of the relationship between plan rules and participant choices. In this paper, we analyze a new data set that enables us to carefully assess many such relationships. The data set is compiled from anonymous administrative records of several large firms that collectively employ almost 200,000 individuals. Many of these companies implemented changes in the design of their 401(k) plans. These plan changes enable us to evaluate the impact on individual savings behavior of institutional variation in 401(k) plan rules. A list of the companies studied in this paper, along with the plan changes or other interventions that we analyze, appears in Table 1. ${ }^{2}$ Appendix A gives a brief description of the data analyzed for each company.

\footnotetext{
${ }_{1}^{1}$ See EBRI Databook on Employee Benefits at http://www.ebri.org/facts/1200fact.htm

2 To maintain the anonymity of the companies described in this paper, we refer to each of them with letters.
} 
Because low employee savings rates have motivated plan administrators to adopt many of the 401(k) plan changes that we discuss in the rest of the paper, we start off in Section II with a discussion of savings adequacy. Using new data from a survey that we designed, we find that two-thirds of employees believe that they are saving too little and that one-third of these selfreported under-savers intend to raise their savings rate in the next two months. By matching survey responses to administrative records, we show that employees who report that they save too little actually do have low 401(k) saving rates. However, almost none of the employees who report that they intend to raise their savings rate in the next two months actually subsequently do so.

This finding introduces a theme that we return to throughout the paper. Specifically, at any point in time employees are likely to do whatever requires the least current effort: employees often follow the "path of least resistance." Almost always, the easiest thing to do is nothing whatsoever, a phenomenon that we call "passive decision." Such passive decision-making implies that employers have a great deal of influence over the savings outcomes of their employees. For example, employer choices of default savings rates and default investment funds strongly influence employee savings levels. Even though employees have the opportunity to opt out of such defaults, few actually do so.

In section III, the heart of our paper, we discuss the impact of changes in seven different types of plan rules. In subsection III.1, we show that automatic enrollment in a 401(k) plan dramatically raises participation rates, but that the vast majority of employees accept the automatic enrollment default contribution rate investment allocation. By contrast, before automatic enrollment was instituted, few employees chose to invest at these defaults.

In subsection III.2, we discuss the effects of automatic cash distributions for terminated employees. We argue that automatic cash distributions, which are given to terminated employees with balances below $\$ 5,000$, undercut retirement wealth accumulation. Most employees with balances below $\$ 5,000$ who receive such automatic distributions consume the proceeds. By contrast, most employees with balances above \$5,000 leave their money in the 401(k) plan. Hence, the automatic cash distributions seem to play a critical causal role in the consumption of these low-balance 401(k) accounts.

In subsection III.3, we discuss different interventions designed to raise employee contribution rates. Benartzi and Thaler (2001b) have shown that employees are willing to 
commit to automatic schedules of slow 401(k) contribution rate increases, and that committing to such a schedule will result in substantially higher 401(k) savings rates after only a few years. We report an experiment of our own that shows that a savings intervention that does not include such an automatic commitment component is not successful.

In subsection III.4, we discuss the effects of the employer match rate and the employer match threshold (the maximum employee contribution that the employer matches) on savings outcomes. We show that adopting an employer match can increase 401(k) participation, and that the match threshold is an important focal point in the selection of employee contribution rates. We also show that increasing the match threshold can raise the contribution rates of households with relatively low saving rates.

In subsection III.5, we discuss the impact of changes in eligibility waiting periods on the 401(k) participation profile (i.e. participation rates plotted against tenure at the job). We show that an increase in the length of wait before $401(\mathrm{k})$ eligibility period truncates, but does not shift, the participation profile.

In subsection III.6, we discuss mutual fund menus and the role of employer, or "company," stock. We argue that the menu of asset allocation options and the choice of the default asset allocation influence actual asset allocation decisions and portfolio diversification.

Finally, in subsection III.7 we discuss the role of financial education in the workplace. Using data that links employees receipt of financial education to their actual savings behavior, we show that although many seminar attendees plan to make 401(k) savings changes, very few actually do so. Thus, while financial education does improve savings outcomes, its effects are modest at best.

We see passive decision-making in many of the behavioral patterns described above. Passive decision-making partially explains the powerful influence of defaults, the anchoring effects of the match threshold, the remarkable success of automatic schedules of slowly increasing contribution rates, and the impact of mutual fund menus on asset allocation decisions.

We conclude the paper by encouraging employers to implement 401(k) plans that work well for decision-makers who often use passive strategies like those described above. Employers and policy-makers need to recognize that there is no such thing as a neutral menu of options for a 401(k) plan. Framing effects will influence employee choices, and passive employee decisionmaking implies that the default options will often carry the day. Sophisticated employers will 
choose these defaults carefully, keeping the interests of both employees and shareholders in mind.

\section{Savings Adequacy}

In January 2001, we administered a saving adequacy survey to a random sample of employees at a large U.S. food corporation (Company A) with approximately 10,000 employees. Of these employees, 1,202 were sent an e-mail soliciting their participation in a Web-based survey on satisfaction with various aspects of the company-sponsored 401(k) plan. ${ }^{3}$ Because participation in the survey was solicited by e-mail and the survey itself was conducted on the Web, the universe of potential respondents is restricted to those with Internet access at work. ${ }^{4}$

Our survey had two different versions. In this section, we discuss the savings adequacy version that was sent to 590 of the employees with computers. From this sample we received 195 usable responses. A copy of the complete survey is reproduced in Appendix B, although we discuss only a subset of the questions in the analysis below. In addition to the survey responses, we also have administrative data on the 401(k) savings choices of survey respondents both before and after the survey. This includes participation decisions, contribution rates, and asset allocation choices from January 1996 through April 2001.

We first asked respondents to report how much they should ideally be saving for retirement. ${ }^{5}$ The average response is 13.9 percent of income. We than asked respondents to evaluate their actual saving rate. Two-thirds (67.7 percent) of the respondents report that their current savings rate is "too low" relative to their ideal saving rate. ${ }^{6}$ One-third (30.8 percent) of the respondents report that their current savings rate is "about right." Only 1 out of 195 respondents ( 0.5 percent) reports that his or her current savings rate is "too high."

To evaluate how well individual perceptions of saving adequacy correlate with actual savings behavior, we report in Table 2 the distribution of actual pre-tax 401(k) savings rates

\footnotetext{
${ }^{3}$ The solicitation included an inducement to actually comp lete the survey: two respondents were randomly selected to receive gift checks of $\$ 250$, and one respondent was selected to receive a gift check of $\$ 500$.

${ }^{4}$ Naturally, restricting our sample to Internet users biases our sample toward employees with greater financial sophistication. Our survey reveals that an employee's level of Internet experience correlates with his self-reported financial knowledge. Likewise, home Internet access also correlates with financial knowledge.

${ }^{5}$ See question 10 from the survey (Appendix B).

${ }^{6}$ See question 11 from the survey (Appendix B). For our empirical analysis we aggregate the categories "far too low" and "a little too low" into one category ("too low"). Likewise, we aggregate the categories "far too high" and "a little too high" into one category ("too high").
} 
conditional on respondents' answers to the savings adequacy questions discussed above. Since we use the plan's administrative records, our analysis of actual 401(k) savings rates does not suffer from reporting biases. We divide the actual pre-tax 401(k) savings rates into three categories: 0 to 4 percent of income, 5 to 8 percent of income, and 9 to 12 percent of income. Our scale tops out at 12 percent because this is the maximum pre-tax 401(k) contribution rate in Company A. Among the respondents who said that their current savings rate is "too low," 36 percent had an actual 401(k) savings rate of 0-4 percent, another 36 percent had a 401(k) savings rate of 5 to 8 percent, and 27 percent had a 401(k) savings rate of 9 to 12 percent. In contrast, among those who said that their current savings rate is "about right," 12 percent had a 401(k) savings rate of 0 to 4 percent, 15 percent had a savings rate of 5 to 8 percent, and 73 percent had a 401(k) savings rate of 9 to 12 percent. These comparisons reveal that respondents who report that their savings rate is too low do have lower actual savings rates than respondents who report that their savings rate is about right. In the former group the average pre-tax 401(k) contribution rate is 5.8 percent of income, in contrast to an average $401(\mathrm{k})$ savings rate of 9.0 percent in the latter group.

We also asked respondents to describe their plans for the future. None of our respondents expressed an intention to lower their contribution rate. But 35 percent of the respondents who said that their savings rate was too low intended to increase their contribution rate over the next few months. By contrast, 11 percent of respondents who said their savings rate was about right intended to increase their contribution rate over the next few months. Among those who planned to raise their contribution rate, over half (53 percent) said that they planned to do so in the next month. Another quarter (23 percent) planned to make the change within two months.

So far our data shows a familiar pattern. Respondents report that they save too little and that they intend to raise their savings rate in the future. Other savings adequacy surveys reach similar conclusions (Bernheim 1995; Farkas and Johnson 1997). Our survey is distinguished by our ability to cross-check responses against actual $401(\mathrm{k})$ records. We have shown that respondents who say that their savings rate is too low actually do have substantially lower pre$\operatorname{tax} 401(\mathrm{k})$ contribution rates. So their retrospective reports are accurate.

We have also checked to see whether their forward-looking plans are consistent with their actual subsequent behavior. Of those respondents who report that their savings rate is too low and who plan to increase their contribution rate in the next few months, only 14 percent of 
this subgroup actually do increase their contribution rate in the four months after the survey. Hence, we find that respondents overwhelmingly do not follow through on their good intentions. In summary, out of every 100 respondents, 68 report that their savings rate is too low; 24 of those 68 plan to increase their 401(k) contribution rate in the next few months; but only 3 of those 24 actually do so. Hence, even though most employees describe themselves as undersavers and many report that they plan to rectify this situation in the next few months, few follow through on this plan.

Needless to say, these data are hard to interpret. It's not clear what subjects mean when they say that they save too little. It's also not clear what subjects mean when they say that they intend to raise their contribution rate in the next few months. However, this evidence is at least consistent with the idea that employees have a hard time carrying out the actions that they themselves say they wish to take. Employers seem to be concerned about such failures. Many of the institutional changes discussed below in Section III were initiated by plan administrators in an effort to raise employee savings rates.

\section{Seven Institutional Features of 401(k) Plans}

In this section, we turn to an analysis of how several different 401(k) plan features affect employee 401(k) savings behavior.

\section{III.1 Automatic Enrollment}

The typical 401(k) plan requires an active election on the part of employees to initiate participation. A growing number of companies, however, have started automatically enrolling employees into the $401(\mathrm{k})$ plan unless the employee actively opts out of 401(k) participation. While automatic enrollment is still relatively uncommon, a recent survey indicates that its adoption has increased quite rapidly over the past few years. ${ }^{7}$

The interest of many companies in automatic enrollment has stemmed from their persistent failure to pass the IRS non-discrimination rules that apply to pension plan provision. As a result of failing these tests, many companies have either had to make ex post 401(k) contribution refunds to highly compensated employees or retroactive company contributions on

\footnotetext{
${ }^{7}$ In a recent survey, Hewitt Associates (2001) reports that 14 percent of companies utilized automatic enrollment in 2001, up from 7 percent in 1999.
} 
behalf of non-highly compensated employees in order to come into compliance. In addition, many companies have tried to reduce the possibility of non-discrimination testing problems by ex ante limiting the contributions that highly compensated employees can make. The hope of many companies adopting automatic enrollment has been that participation among the nonhighly compensated employees at the firm will increase sufficiently that non-discrimination testing is no longer a concern.

While some companies have been concerned about the potential legal repercussions of automatically enrolling employees in the 401(k) plan, the U.S. Treasury Department has issued several opinions that support employer use of automatic enrollment. The first Treasury Department opinion on this subject, issued in 1998, sanctioned the use of automatic enrollment for newly hired employees. ${ }^{8}$ A second ruling, issued in 2000, further validated the use of automatic enrollment for previously hired employees not yet participating in their employer's 401(k) plan. ${ }^{9}$ In addition, during his tenure as Treasury Secretary, Lawrence H. Summers publicly advocated employer adoption of automatic enrollment. ${ }^{10}$

A growing body of evidence suggests that automatic enrollment-a simple change from a default of non-participation to a default of participation—substantially increases 401(k) participation rates. ${ }^{11}$ To assess the impact of automatic enrollment on savings behavior, we examine the experience of three large companies analyzed in Choi, et al. (2001) that implemented automatic enrollment between January 1997 and April 1998. Companies B and C implemented automatic enrollment for new hires. Company D also implemented automatic enrollment for new hires, but in addition, Company D subsequently applied automatic enrollment to non-participating employees who were $401(\mathrm{k})$-eligible at the time when automatic enrollment was initially adopted. ${ }^{12}$

\footnotetext{
${ }^{8}$ See IRS Revenue Ruling 98-30 (Internal Revenue Service 1998).

${ }^{9}$ See IRS Revenue Ruling 2000-8 (Internal Revenue Service 2000a). See also Revenue Rulings 2000-33 and $2000-$ 35 (both Internal Revenue Service 2000b).

${ }^{10}$ See "Remarks of Treasury Secretary Lawrence H. Summers at the Department of Labor Retirement Savings Education Campaign Fifth Anniversary Event" at http://www.ustreas.gov/press/releases/ps785.htm along with related supporting documents.

${ }^{11}$ See Madrian and Shea (2001a), Choi, et al. (2001), Fidelity (2001) and Vanguard (2001).

${ }^{12}$ Because of concurrent changes in eligibility for employees under the age of 40 at Company D, we restrict the sample of employees in the analysis at the company to those aged 40 or over at the time of hire. These employees were immediately eligible to participate in the $401(\mathrm{k})$ plan both before and after the switch to automatic enrollment.
} 
Table 3 illustrates the difference in 401(k) participation rates by tenure before and after automatic enrollment. For each company, we report three columns of figures. The first and second columns contain the fraction of employees hired before and after automatic enrollment was implemented who are 401(k) plan participants at six-month increments of tenure. ${ }^{13}$ The third column differences these participation rates, yielding the incremental impact of automatic enrollment on plan participation.

In all three companies, 401(k) participation for employees hired before automatic enrollment starts out low and increases quite substantially with tenure. At six months of tenure, 401(k) participation rates range from 26 to 43 percent at these three companies. Participation rates increase to 50 to 62 percent at 24 months of tenure, and to 65 to 69 percent at 36 months of tenure. The profile of $401(\mathrm{k})$ participation for employees hired under automatic enrollment is quite different. For these employees, the 401(k) participation rate starts out high and remains high. At six months of tenure, 401(k) participation ranges from 86 to 96 percent at these three companies, an increase of 50 to 67 percentage points relative to $401(\mathrm{k})$ participation rates prior to automatic enrollment. Because 401(k) participation increases with tenure in the absence of automatic enrollment, the incremental effect of automatic enrollment on 401(k) participation declines over time. Nonetheless, at 36 months of tenure, 401(k) participation is still a sizeable 31 to 34 percentage points higher under automatic enrollment.

While most companies that implement automatic enrollment do so only for newly hired employees, some companies have applied automatic enrollment to previously hired employees who have not yet initiated participation in the 401(k) plan. Choi, et al. (2001) show that for previously hired employees at Company D, automatic enrollment also substantially increases the 401(k) participation rate, although the increase in participation is slightly smaller than that seen for newly hired employees. Madrian and Shea (2001a) and Choi, et al. (2001) also discuss how the effects of automatic enrollment vary across various demographic groups. While automatic enrollment increases 401(k) participation for virtually all demographic groups, its effects are

\footnotetext{
${ }^{13}$ Because of differences in the available data from these companies, the numbers across companies are not directly comparable. For Company C, we have data on 401(k) participation on the data collection dates, and thus the numbers in columns 1 and 2 for Company $\mathrm{C}$ represent contemporaneous 401(k) participation rates. For Companies $\mathrm{B}$ and D, we have data on the date of initial 401(k) participation, and thus the numbers in columns 1 and 2 for Companies B and D represent the fraction of employees who have ever participated in the 401(k) plan.
} 
largest for those individuals least likely to participate in the first place: younger employees, lower-paid employees, and Blacks and Hispanics.

One might conclude that since $401(\mathrm{k})$ participation under automatic enrollment is so much higher than when employees must choose to initiate plan participation, automatic enrollment "coerces" employees into participating in the 401(k) plan. However, if this were the case, we should expect to see participation rates under automatic enrollment declining with tenure as employees veto their "coerced" participation and opt out. But remarkably few 401(k) participants at these companies, whether hired before automatic enrollment or hired after, reverse their participation status and opt out of the plan. In our three companies, the fraction of $401(\mathrm{k})$ participants hired before automatic enrollment who drop out in a 12-month period ranges from 1.9 to 2.6 percent, while the fraction of participants subject to automatic enrollment who drop out is only 0.3 to 0.6 percentage points higher. To us, this evidence suggests that most employees do not object to saving for retirement. In the absence of automatic enrollment, however, many employees tend to delay taking action. Thus, automatic enrollment appears to be a very effective tool for helping employees begin to save for their retirement.

While automatic enrollment is effective in getting employees to participate in their company-sponsored 401(k) plan, it is less effective at motivating them to make well-planned decisions about how much to save for retirement or how to invest their retirement savings. Because companies cannot ensure that employees will choose a contribution rate or an asset allocation before the automatic enrollment deadline, the company must establish a default contribution rate and a default asset allocation. Most employees follow the path of least resistance and passively accept these defaults.

Figure 1 shows the distribution of 401(k) contribution rates at our three companies for employees hired before and after automatic enrollment. Because contribution rates may change with tenure, for all three companies we have restricted the sample to employees hired before and after automatic enrollment with equivalent levels of tenure. ${ }^{14}$ All three companies match employee contributions up to 6 percent of compensation, the "match threshold" in Figure 1. But the default contribution under automatic enrollment is much lower than this-2 percent in company B and 3 percent in companies C and D. Before automatic enrollment, 63 to 79 percent

\footnotetext{
${ }^{14}$ In Company B, the sample is restricted to employees with 24-35 months of tenure; in Company D to those with 023 months of tenure; and in Company D to those with 12-35 months of tenure.
} 
of plan participants at these companies contribute at or above the match threshold. Only 11 to 20 percent voluntarily choose the contribution rate specified by their employers as the default under automatic enrollment. In contrast, 42 to 71 percent of participants hired under automatic enrollment contribute at the default rate, while only 26 to 49 percent contribute at or above the match threshold.

Automatic enrollment has similar effects on the asset allocation of plan participants. Figure 2 shows the allocation of 401(k) balances between stocks, bonds and the combination of stable value and money market funds. Once again, because asset allocation may change with tenure, we have restricted the sample to employees with equivalent levels of tenure. ${ }^{15}$ In two of the three companies, the default fund under automatic enrollment is a stable value fund, while in the third it is a money market fund. As Figure 2 shows, employees hired before automatic enrollment have the majority of their plan assets (53 to 81 percent) allocated to the stock market, and only a small fraction of their assets (10 to 18 percent) allocated to stable value or money market funds. These percentages are effectively reversed for employees hired under automatic enrollment. For this group of participants, 48 to 81 percent of assets are invested in stable value or money market funds, a group that includes the automatic enrollment default at all three companies, and only 16 to 51 percent of assets are invested in the stock market. Overall, the fraction of assets allocated to the stock market falls by 22 to 53 percentage points, while the fraction of assets allocated to stable value funds or the money market increases by 31 to 71 percentage points. Choi, et al. (2001) show that these effects are driven both by the conversion of would-be non-participants to the defaults and by employees who would have participated in the absence of automatic enrollment but with different elections.

Given the evidence of delay in the election of $401(\mathrm{k})$ participation before automatic enrollment shown in Table 3, one might speculate that there is the same type of delay in the movement away from the default contribution rate and asset allocation under automatic enrollment. Table 4 suggests that this is indeed the case. At six months of tenure, between 55 and 73 percent of participants contribute at the default and have their assets invested wholly in the default fund. At 24 months of tenure, the fraction of participants at the default falls to 40 to 51 percent, and at 36 months of tenure to 44 to 48 percent. So, with time, employees do move

\footnotetext{
${ }^{15}$ See footnote 14 .
} 
away from the automatic enrollment defaults. Nonetheless, after three years, almost half of participants are still "stuck" at the default. ${ }^{16}$

Taken as a whole, the evidence in this section indicates that defaults can have a powerful effect on the nature of individual saving for retirement. In terms of promoting overall savings for retirement, automatic enrollment as structured by most employers is a mixed bag. Clearly automatic enrollment is very effective at promoting one important aspect of savings behavior, 401(k) participation. This simple change in the default from non-participation to participation results in much higher $401(\mathrm{k})$ participation rates. But, like companies B, C, and D, most employers that have adopted automatic enrollment have chosen very low default contribution rates and very conservative default funds (Profit Sharing/401(k) Council of America 2001; Vanguard 2001). These default choices are inconsistent with the retirement savings goals of most employees.

This evidence does not argue against automatic enrollment as a tool for promoting retirement saving; rather, it argues against the specific automatic enrollment defaults chosen by most employers. Employers who seek to facilitate the retirement savings of their employees need to respond to the tendency of employees to "stick with the default." Employers should choose defaults that foster successful retirement saving when the defaults are passively accepted in their entirety. Automatic enrollment coupled with higher default contribution rates and more aggressive default funds would greatly increase wealth accumulation for retirement. ${ }^{17}$ The results in this section also suggest an important caveat in thinking about the design of personal accounts in a reformed Social Security system—-whatever defaults are chosen will need to be chosen carefully.

\section{III.2 Automatic Cash Distributions for Terminated Employees with Low Account Balances}

Another aspect of 401(k) plan design that highlights the importance of defaults on 401(k) savings outcomes is the treatment of the $401(\mathrm{k})$ balances of former employees. When an employee leaves a firm, the employee may explicitly request a cash distribution, a direct rollover

\footnotetext{
${ }^{16}$ Choi, et al. (2001) show that compensation is the strongest determinant of how quickly employees move away from the automatic enrollment default - highly compensated employees tend to move away from the default more rapidly than those with lower pay.
} 
of 401(k) balances to an IRA, or a rollover to another employer's 401(k) plan. If the terminated employee does not make an explicit request, the balances typically remain in the 401(k) plan. Under current law, however, if the plan balances are less than $\$ 5,000$ and the former employee has not elected some sort of rollover, the employer has the option of compelling a cash distribution.

To document the importance of this mandatory cash distribution threshold, Figures $3 \mathrm{~A}$ and 3B plot the relationship between the size of 401(k) balances and the likelihood that a terminated employee receives a distribution from the 401(k) plan at Companies B and D. We consider the experience of 401(k) participants whose employment terminated any time during 1999 or January through August of 2000. ${ }^{18}$ We order the employees according to the size of their $401(\mathrm{k})$ balances and then divide them into groups of 100 . We then calculate the average balance size for each group (the $\mathrm{x}$-axis, plotted on a log scale) and the average fraction of employees who receive a distribution from the plan by December 31, 2000 (the $y$-axis). The measure of $401(\mathrm{k})$ balances used on the $\mathrm{x}$-axis is the average participant balance as of December 31 of the year prior to the year in which the termination occurred. ${ }^{19}$ This measure of balances is likely to understate the actual balances of plan participants at the time of termination because the incremental contributions made to an individual's account between December 31 of the previous year and the date of termination are excluded (as are any capital gains or losses over this time period).

In both companies, around 90 percent of terminated participants with prior year-end balances of less than $\$ 1,000$ receive a distribution subsequent to termination. In contrast, in Company D, a rather constant one-third of terminated participants with year-end balances of greater than $\$ 5,000$ receive a distribution. In Company $\mathrm{B}$, this fraction is even lower, at about 18 percent, although there is some additional slight decline in the likelihood of receiving a distribution with respect to balance size beyond the $\$ 5,000$ threshold. Between $\$ 1,000$ and $\$ 5,000$ in year-end balances, the fraction of terminated participants receiving a distribution falls rather steadily and quite significantly at both companies. This reflects the decreasing likelihood

\footnotetext{
${ }^{17}$ See section III. 3 for another alternative to a higher initial default contribution rate.

18 This includes both voluntary and involuntary terminations.

${ }^{19}$ That is, employees terminated in 2000 have a balance measure from December 31, 1999, while employees terminated in 1999 have a balance measure from December 31, 1998. We use this measure of balances because it is the only measure that we have in our data.
} 
that terminated participants will have a final balance of less than $\$ 5,000$ that is subject to an involuntary cash distribution.

For example, consider an employee at Company D making $\$ 40,000$ per year who is contributing 6 percent of pay to the $401(\mathrm{k})$ plan with a 50 percent employer match that is vested. If this individual leaves his job at the end of August, the additional employer plus employee contributions to the $401(\mathrm{k})$ plan will amount to $\$ 2,400$. Assuming no net capital gains or losses, this individual will face a mandatory cash distribution if his prior year-end balances were less than $\$ 2,600$ (because $\$ 2,400$ plus anything less than $\$ 2,600$ will fall under the $\$ 5000$ distribution threshold). If his prior year-end balances were higher than $\$ 2,600$, however, the company would not be able to compel a cash distribution because his total balances subsequent to termination would exceed $\$ 5,000$. Thus, employees with higher prior-year-end balances will be less likely to face an automatic distribution upon termination because they are more likely to have had balance increases that bring them above the $\$ 5,000$ threshold.

Of course, even in the case of an automatic cash distribution, the former employee does have the option to roll the account balance over into an IRA or the 401(k) plan of another employer, regardless of the size of the account balance. But previous research suggests that the probability of receiving a cash distribution and rolling it over into an IRA or another 401(k) plan is very low when the size of the distribution is small. Instead, these small distributions tend to be consumed. ${ }^{20}$ When employers compel a cash distribution and employees receive an unexpected check in the mail, it is much easier to consume the distribution than to figure out how to roll it over into an IRA or another employer's 401(k) plan.

This default treatment of the account balances of terminated employees provides another example of how many individuals follow the path of least resistance. When balances exceed $\$ 5,000$, the vast majority of employees leave their balances with their former employer, the least effort option. When balances are below \$5,000 and are subject to a mandatory cash distribution unless the employee elects otherwise, most individuals receive an unsolicited check in the mail and then consume the money rather than rolling it over into another type of saving plan—also the least effort option.

\footnotetext{
${ }^{20}$ Poterba, Venti and Wise (1998) report that the probability that a cash distribution is rolled over into an IRA or another employer's plan is only 5 to 16 percent for distributions of less than $\$ 5000$. The overall probability that a (continued on the next page)
} 
This analysis suggests that the rollover provisions of the recently passed Economic Growth and Tax Relief Reconciliation Act of 2001 (EGTRRA) will indeed have a positive impact on retirement savings. Under the new law, if the account balance is between $\$ 1,000$ and $\$ 5,000$, employers will no longer be able to compel a cash distribution if a former employee does not elect a rollover; rather, employers will be required to establish an IRA on behalf of participants if they choose not to maintain these accounts (Watson Wyatt 2001). Although this provision of the law does not take effect until the Department of Labor issues final regulations regarding implementation, something that is not required to happen until 2004, firms need not wait until then to voluntarily adopt similar measures. As with automatic enrollment in 401(k) plans, default rollovers have also been sanctioned by the IRS. ${ }^{21}$ Such a change in the default treatment of the small balances of terminated employees is a simple step that would further enhance the retirement savings plans of many individuals. ${ }^{22}$

\section{III.3 Automatic Contribution Rate Increases}

One 401(k) plan feature designed to capitalize on the inertia described in sections III.1 and III.2 is the "Save More Tomorrow" ("SMarT") plan developed by Shlomo Benartzi and Richard Thaler (Benartzi and Thaler 2001b). Under this plan, participants commit in advance to saving a portion of future raises. For example, suppose that a worker commits to allocate onehalf of future nominal pay raises to increases in his 401(k) contribution rate. If the worker receives three percent raises in each of the following three years, then his contribution rate would rise by 1.5 percentage points per year over this time period. This plan is carefully constructed to make use of several themes in behavioral economics. By requiring a present commitment for future actions, the SMarT plan alleviates problems of self-control and procrastination. And by taking the additional savings out of future salary raises, participants in the SMarT plan are not hurt by loss aversion because workers will never see a reduction in their nominal take-home pay.

cash distribution is rolled over into an IRA or another employer's plan or invested in some other savings vehicle is slightly higher at 14 to 33 percent.

21 See Revenue Rulings 2000-36 (Internal Revenue Service 2000b).

${ }^{22}$ We should note, however, that previous research also suggests that although small distributions tend to be consumed rather than rolled over into other retirement savings vehicles, these small distributions represent a relatively small fraction of total retirement savings (Poterba, Venti and Wise 1998). Thus, while automatically rolling such distributions over into an IRA will undoubtedly increase retirement saving, its impact on aggregate retirement saving is likely to be modest. 
(This presumes that participants are subject to money illusion because the commitment to save is out of nominal salary increases).

The striking results of the first experiment with the SMarT plan are reported in Benartzi and Thaler (2001b). This first experiment was conducted at a mid-size manufacturing company. This company, which did not match employee contributions, was experiencing problems in getting low-salary workers to participate and contribute at high levels to the 401(k) plan. To combat these problems, the company hired an investment consultant to meet with employees and help them plan their retirement savings. After an initial interview with each employee, the consultant would gauge the employee's willingness to increase his savings rate. Employees judged to have a high willingness to save more would receive an immediate recommendation for a large increase in their savings rate. 79 workers fell into this group. Employees judged to be reluctant to save more would be offered the option of enrolling in the SMarT plan. 207 workers fell into this group. The version of the SMarT plan that was implemented set up a schedule of annual contribution rate increases of three percentage points. This is a relatively aggressive implementation, as the annual nominal salary increases at this company were only a little bit higher than three percent.

The results of the experiment show that the SMarT plan can have an enormous impact on contribution rates. Of the 207 participants offered the SMarT plan as an option, 162 chose to enroll. Furthermore, 129 of these 162 (80 percent) stayed with the plan through three consecutive pay raises. At the beginning of the SMarT plan, these 162 workers had an average contribution rate of 3.5 percent; by the time of their third pay raise, these workers (including those that eventually dropped out) had an average contribution rate of 11.6 percent. Recall that these original 207 participants were selected from a larger sample based on their relative reluctance to increase their savings rates. In comparison, 79 workers had indicated a willingness to increase their contributions immediately and were never enrolled in the SMarT plan; these workers increased their average contribution rate from 4.4 percent to 8.7 percent over the same time period. Since it is reasonable to assume that this latter group of workers represents a more highly motivated group of savers than the SMarT plan participants, the increases by the SMarT plan participants are very striking. As a further comparison, consider that the median 401(k) contribution rate of participants in 401(k) plans in general is approximately 7 percent of pay (Investment Company Institute 2000). Thus, the SMarT plan participants went from half of this 
median contribution rate before signing up for the SmarT plan to a contribution rate 50 percent higher three years later.

Despite the clear success of the SMarT plan in increasing contribution rates, there remain several important caveats. First, the plan is not guided by any well-specified model of what ideal savings should be. Even if we accept that cleverly designed commitment devices can enable workers to break from suboptimal behavior patterns, these same devices may overshoot the optimal targets. Second, the increases in 401(k) contribution rates may be offset by dissaving elsewhere. $^{23}$ Although $401(\mathrm{k})$ saving has many advantages, it may still be inefficient if it leads participants to increase high-interest credit-card debt. Also, we do not know how much of the additional contributions were later reduced by plan loans or hardship withdrawals. In a plan that does not have an employer match—like the one used in the original SMarT experiment—it is not clear that increasing 401(k) contributions is always a good idea. Notwithstanding these caveats, the SMarT plan is certainly a provocative attempt to use behavioral economics to increase savings rates, and the early results are highly encouraging and deserve further study.

Our 401(k) survey (discussed in Section II) sheds light on the mechanisms that make the SMarT plan work. We generated two versions of our survey. One version (already discussed above) asked questions about both savings adequacy and intentions regarding planned future investment changes (e.g. plans to change the contribution rate and the asset mix). We call this the savings adequacy version. We also generated a pared down version of the survey that contained no questions about either savings adequacy or intentions. We call this the control version. We randomly assigned the two different versions of the survey to employees and we checked to see whether the savings adequacy questionnaire had an impact on subsequent 401(k) investment choices. In other words, we looked to see whether the process of thinking about savings adequacy and formulating one's future savings plans actually led to a greater propensity to subsequently increase (or decrease) one's saving rate.

It turns out that this attention manipulation had no impact. In other words, getting someone to think about his or her own savings adequacy did not lead to any differential future behavior. This result sheds some light on the success of the SMarT plan. The SMarT plan has

\footnotetext{
${ }^{23}$ See Engen, Gale, and Scholz $(1994,1996)$ for a discussion of asset shifting and its consequences for measuring 401(k) effectiveness. See Poterba, Venti, and Wise (1996, 1998b) for evidence that asset shifting effects are not large.
} 
many different effects. It encourages employees to think about their savings adequacy. It also sets in motion a series of automatic contribution rate increases. Our survey experiment demonstrates that getting employees to think about savings inadequacy is not enough. Employees also need a low-effort mechanism to help them to carry out their plans to increase their contribution rate. The SMarT plan provides exactly such a tool.

\section{III.4 Matching}

Although automatic enrollment and the SmarT plan provide lots of food for thought, they are still relatively new $401(\mathrm{k})$ plan features that have yet to be adopted on a widespread scale. A more common feature of $401(\mathrm{k})$ plans is the employer match. For each dollar contributed by the employee to the plan, the employer contributes a "matching" amount up to a certain threshold (e.g. 50 percent of the employee contribution up to 6 percent of compensation). Although the effects of employer matching on 401(k) participation and contribution rates have been widely studied, the conclusions from this research are decidedly mixed. This derives in part from the inherent difficulties associated with identifying the impact of matching on 401(k) savings behavior.

In theory, introducing an employer match should increase participation in the 401(k) plan. In practice, however, it is difficult to disentangle this effect from the potential correlation between the savings preferences of employees and the employer match. For example, companies that offer a generous $401(\mathrm{k})$ match may attract employees who like to save, biasing upward the estimated impact of an employer match on 401(k) participation.

Using cross-sectional data, Andrews (1992), Bassett, Fleming and Rodrigues (1998), Papke and Poterba (1995), Papke (1995), and Even and Macpherson (1997) all find a positive correlation between the availability of an employer match and $401(\mathrm{k})$ participation. The results are more varied, however, in studies that attempt to control for the correlation between the employer match and other unobserved factors that affect 401(k) savings behavior. Even and Macpherson (1997) use an instrumental variables approach to account for the endogeneity of the employer match and still find a large positive impact of matching on 401(k) participation. However, it is not clear that the firm characteristics they use as instrumental variables are in fact uncorrelated with unobservable employee savings preferences. Because she uses longitudinal data on firms, Papke (1995) is able to include employer fixed effects to account for the 
correlation between the employer match and other factors that affect savings behavior. With the addition of these fixed effects, the relationship between the employer match and 401(k) participation goes away, but these results are difficult to interpret because Papke only observes average match rates, not marginal rates. Kusko, Poterba, and Wilcox (1998) examine several years of individual-level data in a company whose match rate varied from year to year based on the company's prior-year profitability. They also find no relationship between the match rate and 401(k) participation. However, the transient nature of the match rate changes at this company make it difficult to extrapolate these results to the permanent types of match changes that most companies are likely to consider.

The empirical evidence on matching and $401(\mathrm{k})$ contribution rates is even less decisive than that on 401(k) participation, although in theory the effects here are less straightforward as well. While introducing an employer match where there wasn't one before should lower the contribution rates of employees who were already contributing in excess of the match threshold (an income effect), its impact on those previously contributing at or below the match threshold is ambiguous (opposing income and substitution effects). The effects would be similar for increasing the match rate while maintaining the same match threshold. Increasing an existing non-zero match threshold while keeping the match rate constant should have no effect on people contributing below the old threshold; increase contributions for people at the old threshold (a substitution effect); have an ambiguous effect for people above the old threshold but at or below the new threshold (opposing income and substitution effects); and decrease contribution rates for people above the new threshold (an income effect).

The actual empirical research on matching and 401(k) contribution rates has focused largely on the relationship between the match rate and average 401(k) contribution rates. Andrews (1992) finds that a higher employer match rate reduces the average 401(k) contribution rate; Bassett, Fleming and Rodrigues (1998) find no effect; Papke and Poterba (1995) and Even and Macpherson (1997) find a positive relationship; and Kusko, Poterba, and Wilcox (1998) find a small but positive effect of the match rate on average 401(k) contribution rates. Papke (1995) finds a positive effect of the match rate on total employee contributions at low match rates, but a negative effect on employee contributions at higher match rates. These disparate results are perhaps not so surprising given that theory has little to say about the impact of the match rate per se on the average $401(\mathrm{k})$ contribution rate. 
In this paper, we are able to avoid some of the confounds of previous matching studies by examining the individual behavior of participants before and after permanent changes in the 401(k) match structure at two companies. In these natural experiments, participant behavior before the changes serves as a control for participant behavior after the changes. We also examine the effect of matching on the distribution of $401(\mathrm{k})$ contribution rates rather than on the average $401(\mathrm{k})$ contribution rate and show the importance of considering the match threshold, a facet of employer matching largely ignored in previous research, as well as the match rate.

The first company that we consider, Company E, increased its match threshold on January 1, 1997, while keeping its match rate constant. Before that time, union workers received a 50 percent match on the first 5 percent of income contributed to the $401(\mathrm{k})$ plan, while management employees received a 50 percent match on the first 6 percent of income. On January 1, 1997, the match threshold for union employees increased to 7 percent, while that for management employees increased to 8 percent. Contributions up to the new threshold were still matched at 50 percent, although the match on the incremental 2 percent of the new threshold was invested in employer stock while the match up to the old threshold had been, and continued to be, invested at the discretion of the employee.

To examine the impact of this change in the match structure on $401(\mathrm{k})$ savings behavior, we utilize a combination of both longitudinal and cross-sectional data. We have longitudinal data on the 401(k) contribution rate in effect on each day from March 31, 1996 to February 28, 2000 for every worker who was enrolled in the 401(k) plan during that time. We also have crosssections of all active employees at Company E at year-end 1998, 1999, and 2000 that contain information on participation status, original enrollment date, original hire date, and demographics.

In order to assess the effect of the threshold change on participation, we estimate a Cox proportional hazard model of time from hire until the date of initial participation in the 401(k) plan. We control for gender and age (with both linear and quadratic terms), and also include a dummy variable that equals 1 after the new threshold took effect (January 1, 1997). We exclude all employees hired before January 1, 1996 because the company eliminated its length-of-service requirement for 401(k) participation on that date. We also exclude employees hired after December 31, 1997 because the company switched from a traditional defined benefit to a cashbalance pension plan at that time for newly hired employees. The first column of Table 5 
presents the estimated hazard ratios associated with each independent variable. As one might expect for a change that does not affect the marginal incentives to participate in the 401(k) plan, we find that this increase in the match threshold has no significant effect on 401(k) participation.

We next look at the impact of the threshold change on 401(k) contribution rates. Figure 4 plots the distribution of contribution rates over time for all workers who were contributing to the 401(k) plan on March 31, 1996. As workers leave the firm, they are dropped from the sample. The switch from the old threshold to the new threshold is clearly apparent. There is an immediate jump from the old threshold to the new threshold when the change occurred in January 1997, and a continued slower adjustment over the next three years as more and more people shift from the old to the new threshold. This suggests that there is a strong substitution effect for contributors at the old threshold. In contrast, the fraction of participants at the other contribution rates is fairly stable over this entire time period, implying only a very small income effect for contributors above the old threshold.

The shift in contribution rates from the old to the new match threshold may also reflect an "anchoring effect" of the match threshold. Specifically, the match threshold serves as a salient starting point in the decision of which contribution rate to select. Numerous studies have shown that final decisions tend to be anchored by such starting points (Kahneman and Tversky 1974).

The second company that we consider is Company F, which introduced a 25 percent match on contributions up to 4 percent of income on October 1, 2000. We suspect that this was adopted as a response to the fact that at year-end 1999, only 34 percent of its active employees had ever participated in its $401(\mathrm{k})$ plan. ${ }^{24}$ Communication about the change started at the beginning of July 2000. Prior to this date, there was no employer match offered in the plan. ${ }^{25}$

Our data include cross-sections of all active employees at Company $\mathrm{F}$ at year-end 1998, 1999, and 2000. These data contain information on participation status, original enrollment date, effective year-end contribution rate, original hire date, and demographics. We exclude all employees hired before July 1, 1998 because on that date the company eliminated a one-year length-of-service requirement for 401(k) eligibility.

\footnotetext{
${ }^{24}$ We should note that Company $\mathrm{F}$ has a primary defined benefit pension plan for its employees.

25 The company did have three acquired divisions that had employer matches previously and were not affected by this change. These divisions, as well as three divisions that were acquired after 1998, are excluded from our analysis.
} 
To assess the impact of the employer match on 401(k) participation, we again estimate a Cox proportional hazard model of time from hire until the date of initial participation in the 401(k) plan. As with company E, we control for gender and age, and we include a dummy variable that equals 1 after the match was announced to employees (July 2000). Results are presented in column 2 of Table 5. We find that introducing the match has a positive and highly significant effect on participation, with a z-statistic of 6.84. In order to assess the economic significance of the results, we plot in Figure 5 the predicted participation rate by tenure for a hypothetical population of 40-year-old males. At three to four months of tenure, the model predicts a 10.9 percent participation rate when there is an employer match, which is 3.4 percentage points higher than would be the case without an employer match. Results at longer tenure levels are more speculative because we don't actually observe employees with more than three months of tenure who have had the match in place since hire. Keeping this caveat in mind, we see that the model predicts 17.8 percent participation at one year after hire with an employer match (a 5.3 percentage point increase) and 24.2 percent participation at two years of tenure (a 7.0 percentage point increase).

Although these numbers may seem small, note that this company had unusually low participation rates to start with. When compared against the baseline, the employer match appears to have increased $401(\mathrm{k})$ participation by over 40 percent. Furthermore, relative to the match structure in other 401(k) plans, this employer match is not particularly generous. ${ }^{26} \mathrm{~A}$ higher match rate might be expected to have a larger effect on participation. ${ }^{27}$

The introduction of a match seems to have had a meaningful effect on the distribution of contribution rates as well. Figure 6 is a histogram of contribution rates by hire cohort at the end of the calendar year in which the cohort was hired. ${ }^{28}$ Before the employer match, the most frequently chosen contribution rates of plan participants are 5 percent, 10 percent, and 15 percent (which is lumped together with the 11 to 14 percent rates in the graph). After the employer match, we see a large increase in the fraction of employees with a 4 percent contribution rate, the

\footnotetext{
${ }^{26}$ The modal employer match is $50 \%$ of employee contributions up to $6 \%$ of compensation (Bureau of Labor Statistics, 1998).

${ }^{27}$ However, Bassett, Fleming, and Rodrigues (1998) conclude that the mere presence of a match increases participation, with no marginal effect from increasing the match rate. We cannot test this hypothesis with our data.

${ }^{28}$ While the distribution of employees at the various contribution rates is based on the full sample of employees, not just plan participants, we have excluded the non-contributors from the graph because they constitute over 90 percent (continued on the next page)
} 
new match threshold, relative to previous cohorts with the same level of tenure at the company. This is consistent with our previous observation that the match threshold may serve as a powerful focal point in employees' choice of a contribution rate.

In sum, our limited evidence suggests that employer matching does have a significant impact on both 401(k) participation and contribution rates. Company $\mathrm{F}$ demonstrates that implementing an employer match can increase 401(k) participation. Company E demonstrates that increasing the match threshold can increase 401(k) contribution rates. Both Company E and Company F show that the level of the match threshold has an important effect on the distribution of $401(\mathrm{k})$ contribution rates, with many participants clustering at the match threshold.

\section{III.5 Eligibility}

Another common 401(k) plan feature is a waiting period before employees become eligible to participate in the 401(k) plan. Employers adopt eligibility requirements for a variety of reasons, including the fixed costs of administering accounts for newly hired workers with high turnover rates, and because low participation rates of newly hired employees may adversely affect an employer's non-discrimination testing. This latter explanation, however, is less relevant as recent legislative changes have made it easier for companies to institute shorter length-of-service requirements for 401(k) participation without substantially increasing the company's risk of failing non-discrimination tests.

Earlier eligibility is valuable for employees since a shorter waiting period increases their tax-deferred savings opportunities. The extent of this benefit, however, depends on how waiting periods affect the participation profile, the relationship between $401(\mathrm{k})$ participation and tenure. For example, waiting periods may merely truncate the participation profile, so that upon eligibility, employee participation quickly catches up to the participation rate that would arise without a waiting period. Alternatively, waiting periods may shift the participation profile, so that employees who face a waiting period have permanently lower $401(\mathrm{k})$ participation rates than those who do not.

In this subsection, we examine the effect of eligibility requirements on 401(k) participation in two companies that eliminated their eligibility requirements. Both Company $\mathrm{F}$

of the sample, and including them makes variation in contribution rates across the contributing population difficult to see. 
and Company $\mathrm{G}$ went from a one-year eligibility period to immediate eligibility-Company $\mathrm{F}$ on July 1, 1998, and Company G on January $1,1997 .^{29}$

To illustrate the impact of waiting periods on 401(k) participation, we plot in Figures 7A and 7B the 401(k) participation profiles of employees who faced either a one-year or no eligibility requirement. For Company F (Figure 7A), the two groups are employees hired between July 1, 1996 and July 1, 1997 with a full one-year waiting period, and employees hired between July 1, 1998 and December 31, 2000, who faced no waiting period. For Company G (Figure 7B), the two groups are employees hired between January 1, 1995 and January 1, 1996 with a full one-year waiting period, and employees hired between January 1, 1997 and December 31, 1999 with no waiting period.

At both companies, the employees with a one-year waiting period do not immediately attain the 401(k) participation levels achieved at equivalent tenure levels by employees with shorter waiting periods, but this gap closes fairly quickly over time. If we assume that the participation series are drawn independently, the differences between the two groups are no longer statistically significant at 18 months of tenure in Company $\mathrm{F}$ and at 22 months of tenure in Company G.

Another way to look at these participation profiles is to consider participation rates by the time since 401(k) eligibility. Doing so, we see that conditional on time since becoming eligible, employees with a one-year eligibility requirement actually have a higher 401(k) participation rate than employees who were immediately eligible. The difference in participation rates is between 2.5 and 4.6 percentage points for Company $\mathrm{F}$ and always significant at the 1 percent level for the first twelve months after eligibility. At Company $\mathrm{G}$ the difference is approximately 7 percentage points and is almost always significant at the 1 percent level for the first 24 months after eligibility. These findings are inconsistent with the notion that eligibility requirements simply shift the 401(k) participation profile without affecting its shape.

Overall, the evidence from these two companies suggests that the 401(k) participation rates of employees who face eligibility requirements catch up fairly quickly (within a matter of months) to levels that would occur without waiting periods. While this is certainly better for

\footnotetext{
${ }^{29}$ Company $\mathrm{G}$ also subsequently changed the windows in which participants could enroll in the plan. Prior to September 1, 1997, participants could enroll only once a month. Beginning on November 22, 1997, however, new (continued on the next page)
} 
retirement wealth accumulation than would be the case if eligibility requirements resulted in permanently lower 401(k) participation rates, we do not take this as evidence to suggest that waiting periods are "not that bad." Nobody seems to lose when shorter waiting periods are adopted, so we see no reason why companies should not be encouraged to allow immediate eligibility for participation in 401(k) savings plans.

\section{III.6 Asset Allocation Choices}

The bulk of this paper is focused on the 401(k) participation and contribution decisions of employees. If we are concerned about savings adequacy at retirement, the questions of "whether to participate in a savings program" and "how much to save conditional on participation" are of primary importance. After these two questions have been answered, the next most important question is "how to allocate savings among different asset classes." A small but growing literature has addressed these questions in recent years; not surprisingly, many of the same behavioral issues present in the participation and contribution decisions also play a role in participants' asset-allocation choices. As discussed earlier, Madrian and Shea (2001a) and Choi, et al. (2001) show that automatic enrollment results in many participants remaining at the employer-specified default for both the contribution rate and asset allocation.

Such passive decision-making in asset allocation choices is also present in many other guises. In a series of papers, Shlomo Benartzi and Richard Thaler demonstrate several related behavioral regularities in asset-allocation decisions. Benartzi and Thaler (2001a) study the relationship between the menu of investment choices and the eventual pattern of asset holdings across different classes. They suggest that participants use naive diversification strategies that are heavily influenced by the menu offered by their plan; a plan sponsor that offers ten equity options and five non-equity options may be subtly influencing its employees to put two-thirds of their money into equities. Using a database of 170 retirement savings plans, Benartzi and Thaler (2001a) find that approximately 62 percent of the funds offered in these plans are equity investments; the fraction of total assets held in equities by the participants in these 170 plans is remarkably close to 62 percent as well. Furthermore, they find a positive relationship at the plan level between the fraction of equity funds offered by the plan and the fraction of individual

enrollments were allowed on a daily basis. To the extent that these deadline changes affect the time path of participation, Company G's results could be biased. 
portfolios invested in equities. These findings are further reinforced by experimental data and by evidence on individual decisions made by TWA pilots in their corporate plan.

In another study, Benartzi and Thaler (2001c) gave participants a choice between the distribution of retirement outcomes implied by the actual asset allocation in their 401(k) plan and the distribution implied by the average allocation among all participants in the same plan. Most participants preferred the average distribution to the one based on their own allocation. Since most participants have portfolios that are, almost by definition, more extreme than the average allocation, Benartzi and Thaler characterize this result as an example of an aversion to "extremeness." Such results call into question whether most participants are choosing an allocation that could be called optimal in an economic framework.

Perhaps the most disturbing aspect of 401(k) participants' asset allocation choices is the large fraction of balances invested in employer stock. About half of all 401(k) plans (by assets) offer participants the opportunity to invest in company stock. Some plans even require that all matching contributions be held in company stock, at least for some period of time. Because this asset class is both very volatile (since it consists of only a single stock) and highly correlated with the labor earnings of employees, holding company stock is certainly a poor diversification strategy for participants. Nevertheless, a significant fraction of plan assets are held in company stock. For firms that offer company stock in their plans, Holden, VanDerHei, and Quick (2000) find that about 33 percent of plan assets are held in this asset class. Among all firms, including those that do not offer company stock, this fraction is 18 percent.

While this level of holdings itself seems high, the manner in which participants decide to invest in company stock is also troubling. Benartzi (2001) finds that current contributions to company stock are heavily influenced by the returns earned by that stock over the preceding ten years. It seems that naive diversification is combined with naive extrapolation of past returns and an apparent lack of concern for the risk consequences of company stock investment. Indeed, a first-order improvement in diversification could be gained by the simple elimination of company stock from 401(k) plans.

Interestingly, ERISA restricts the investments of defined benefit pension plans in the stock or real estate of the employer to $10 \%$ of total assets. 401(k) plans, however, are exempt from this rule. The combination of large-scale layoffs and the stock market decline after April 2000 has finally brought some public attention to the diversification danger of company stock in 
401(k) plans. 401(k) industry professionals are watching with great interest a recent class-action lawsuit brought by participants in Lucent's 401(k) plan. As reported by the trade publication Pensions \& Investments, the suit claims that "Lucent tried to induce plan participants to invest in, or maintain investments in, company stock, even though certain company officers knew of serious business problems that made Lucent stock an inappropriate investment since year-end 1999." ${ }^{30}$ Lucent stock fell over 90 percent from the end of 1999 to mid-2001, and as late as mid2000, over 40 percent of Lucent's 401(k) plan assets were still invested in Lucent stock. This lawsuit has led other companies to reconsider the emphasis of company stock in their 401(k) plans, with some considering the elimination of matching in company stock, and other the elimination of its availability as an investment option altogether. A successful lawsuit by Lucent's plan participants may finally catalyze a nationwide reponse to the problem of inappropriate diversification.

\section{III.7 Financial Education at the Workplace}

Recognizing that many employees are ill-equipped to make well-informed retirement savings decisions, particularly with respect to asset allocation, many employers have turned to various forms of financial education provision to help their employees meet the challenges of planning for an economically secure retirement. These efforts, which vary widely across employers, run the gamut and include paycheck stuffers, newsletters, summary plan descriptions, seminars, individual consultations with financial planners, and more recently, access to Internetbased education and planning tools.

The previous literature on the effects of financial education on savings behavior has found rather consistent evidence that financial education positively impacts savings behavior, although the inadequacy of the data in many of these studies makes their conclusions somewhat speculative. There are two broad strands in the literature. The first is case studies of the impact of financial education at specific companies or organizations. These studies typically evaluate the effect of a particular financial education initiative, often financial education seminars, on either savings behavior or measures of financial well being (Kratzer et al. 1998; HR Focus 2000; DeVaney et al. 1995; McCarthy and McWhirter 2000; Jacobius 2000). While all of these studies

\footnotetext{
${ }^{30}$ This quote and data on Lucent's plan are taken from Pensions and Investments, Sept. 3rd, 2001, Page 10.
} 
conclude that financial education motivates improvements in savings behavior, these conclusions are often based on dramatic changes in what participants plan to do with respect to retirement saving without actually verifying that the prophesied changes eventually do take place.

Unfortunately, a growing body of both theoretical and empirical evidence, including the survey results reported in Section II of this paper, suggests that despite the best intentions of employees, retirement saving is one area in which individuals excel at delay (Madrian and Shea 2001a; O’Donoghue and Rabin 1998; Diamond and Koszegi 2000; Laibson, Repetto and Tobacman 1998). Thus, measures of intended behavior are likely to dramatically overstate the actual effects of financial education.

The second broad category of analyses in the previous literature on financial education has utilized cross-sectional surveys of individuals from across the population, not just from a single company or organization (Bernheim and Garrett 1996; Bernheim, Garrett and Maki 1997; Milne, Vanderei and Yakaboski 1995), or data from surveys of multiple employers (Bayer, Bernheim and Scholz 1996; Milne, Vanderei and Yakaboski 1996; Murray 1999). This category of studies has the advantages of applying to a general population and utilizing actual savings choices instead of savings intentions.

However, the cross-sectional datasets also pose numerous problems. The greatest drawback to these datasets is that financial education provision and/or utilization may be correlated with other factors that have a strong influence on savings behavior across individuals or organizations (e.g. the structure of the 401(k) plan, the availability of other types of savings and/or pension programs, the level and structure of employee compensation, the corporate culture). To the extent that these confounding factors are not completely observed and controlled for, the measured effects of financial education could be quite biased. The definition of what constitutes "financial education" is also subject to interpretation and is likely to vary from one respondent to another.

The household surveys have the additional disadvantage that survey answers to questions about financial education are likely to be subject to recall bias. This could result, for example, if individuals who participate in and benefit the most from employer-sponsored savings programs find financial education more salient and are thus more likely to remember that such programs were offered. This type of non-random measurement error in the "availability" of financial education will lead to estimates of the effects of financial education that are too large. The 
employer-based surveys have the additional disadvantage that response rates tend to be quite low, and it is unlikely that the non-response is random. Moreover, it is almost impossible to determine how the selection of the firms into the sample is likely to impact the results.

A recent study by Madrian and Shea (2001b) examines the impact of financial education seminars on savings behavior in Company $\mathrm{C}$, one of the companies discussed in section III.1. Company $\mathrm{C}$ enlisted a financial education provider to give one-hour seminars at its various locations throughout the country during 2000. The curriculum at these seminars was general in nature, and covered topics directly related to retirement savings such as setting savings goals to meet retirement income targets and the fundamentals of investing (asset classes, risk, diversification, etc.), in addition to more general financial issues such as managing credit and debt and using insurance to minimize exposure to financial risks.

The financial education data from this company are unique in that seminar attendance was tracked in a way that made it possible to match seminar attendance to administrative data on both previous and subsequent savings behavior. We have data the individuals who attended financial education seminars between January 1 and June 30, 2000, and on the 401(k) savings choices of all employees at this company on December 31, 1999, before any of the seminars were offered, and on June 30, 2000, by which time the seminars had been offered at 42 different locations. One-third of the employees at the company work at these 42 locations, and about 17 percent of employees at these locations attended the financial education seminars.

Table 6 presents some very basic statistics on the planned changes in savings behavior that attendees of the financial education seminars reported, along with the actual changes in savings behavior that were made subsequent to the seminars. The statistics in Table 6 paint a somewhat more muted picture of the impact of financial education on savings behavior than has been estimated in the previous literature. In an evaluation of the financial education seminars given to attendees at the conclusion of the seminar, attendees were asked, "After attending today's presentation, what, if any, action do you plan on taking toward your personal financial affairs?" followed by a list of choices (with multiple responses allowed). 71 percent of those attending the seminars filled out and turned in these evaluation forms. ${ }^{31}$

\footnotetext{
${ }^{31}$ The evaluation responses that we have are from all locations offering financial education seminars during 2000 , not just those offering the seminars during the January-June 2000 period for which we have savings data. Unfortunately, we do not have the evaluation responses on an individual basis, only the aggregrated responses for all (continued on the next page)
} 
Of those who filled out the evaluation, 12 percent reported that they intended to start contributing to the 401(k) savings plan. But 88 percent of seminar attendees were already participating in the $401(\mathrm{k})$ plan, so virtually all of the non-participating seminar attendees planned to enroll in the 401(k) plan. By June 30, 2000, however, only 14 percent of the nonparticipating seminar attendees had actually joined the plan, and some of these individuals would likely have enrolled in the 401(k) plan without the availability of a financial education seminar (as did 7 percent of the employees who did not attend the seminars).

Of those seminar attendees who were already participating in the plan, 28 percent reported plans to increase their $401(\mathrm{k})$ contribution rate, 41 percent reported plans to make changes in the selection of their investment choices within the $401(\mathrm{k})$ plan, and 36 percent reported plans to change the fraction of their money allocated to the various $401(\mathrm{k})$ investment choices. By June 30, 2000, however, only 8 percent of 401(k) participants attending the seminars had increased their contribution rate, while 15 percent had made changes to their investment choices and 10 percent had changed their fund allocations. While the fraction of seminar attendees making such changes is slightly higher than the fraction of non-seminar attendees, it is substantially below what the attendees reported they planned on doing. One could certainly argue that the low rate of actual changes relative to planned changes results from the fact that the data used to observe the plan changes is, for employees at some locations, not long after the actual financial education seminars. However, there is relatively little correlation between the fraction of seminar attendees making changes to their 401(k) savings behavior and the length of time between their seminar and June 30, 2000. It appears that seminar attendees either make changes almost immediately or not at all.

Madrian and Shea (2001b) draw similar conclusions when they try to control for differences in the underlying savings propensities of employees who do and do not attend financial education seminars. Their final assessment is that financial education increases savings plan participation and results in greater portfolio diversification, particularly among employees hired under automatic enrollment, but the estimated magnitudes are not particularly large. Overall, while financial education is important, it does not appear to be a powerful mechanism for encouraging 401(k) retirement savings.

attendees. Thus, we cannot ascertain on an individual basis how many seminar attendees actually followed through on the planned behaviors listed on the evaluation form. 


\section{Conclusions}

The evidence discussed above provides an incomplete sketch of the retirement preparation process. Our analysis only covers $401(\mathrm{k})$ savings and necessarily misses other important types of wealth like home equity, IRAs and defined benefit pensions. However, even our incomplete evidence provides intriguing hints about the economic and psychological forces that drive financial planning.

Most of our evidence highlights the importance of passive decision-making. For better or for worse, many households appear to passively accept the status quo. For example, in companies without automatic enrollment, the typical employee takes over a year to enroll in his or her company-sponsored 401(k) retirement plan. In companies with automatic enrollment, employees overwhelmingly accept the automatic enrollment defaults, including default savings rates and default funds. For terminated employees, the key determinant of whether they consume or save their $401(\mathrm{k})$ balances is whether that balance is above or below the automatic cash distribution threshold of $\$ 5,000$. Many plan participants allow the menu of investment funds to drive their asset allocation decisions. Most employees feel that they save too little, and many plan to raise their contribution rate in the near future, but few act on these good intentions. By contrast, employees do succeed in raising their contribution rates if they are given a loweffort opportunity to sign up for an automatic schedule of increases in their contribution rate.

All of these examples have a common theme: employees often take the path of least resistance. As a result, employers have a large measure of control over the savings choices that their employees make, and employers cannot escape this responsibility. Whatever savings plan an employer creates necessarily advantages certain passive or nearly passive choices over other active choices. Sophisticated employers should choose their plan defaults carefully, since these defaults will strongly influence the retirement preparation of their employees.

Policy-makers should also recognize the role of defaults, since policy-makers can facilitate, with laws and regulations, the socially optimal use of defaults. For example, default contributions to company stock may lead to insufficient diversification. Policymakers could legally cap default investments to such problematic asset categories. Likewise, policymakers could facilitate default contributions to more appropriate investments, like the S\&P 500, by giving corporations legal protections for picking such risky but highly diversified default funds. 
It is easy to identify dozens of ways that thoughtful regulations can influence passive decision-makers without encroaching on the freedom of active decision-makers to opt out of the defaults and choose in their own (perceived) best interest. However, regulating defaults is a twoedged sword. If one has confidence in the government, then such regulations will serve the common good. If one does not have such confidence, then regulating defaults will open up one more avenue for the misuse of governmental power. Our analysis demonstrates that defaults matter, but our evidence does not reveal who should control them. 


\section{Appendix A: Data}

This Appendix describes the data for each of the companies analyzed in this paper.

Company A. 1) Cross-sectional survey data from January 2001 for a random sample of employees; 2) Longitudinal 401(k) savings data from January 1996 through April 2001 for all 401(k) participants.

Company B. Cross-sectional 401(k) savings data from December 31 of 1998, 1999 and 2000 for all active employees (both 401(k) participants and non-participants) and non-employee 401(k) plan participants.

Company C. 1) Cross-sectional 401(k) savings data from June 1, 1997; December 31, 1997; June 30, 1998; December 30, 1998; March 31, 1999; June 30, 1999; September 30, 1999; December 31, 1999; March 31, 2000; and June 30, 2000 for all active employees; 2) Financial education seminar attendees from January 1, 2000 through June 30, 2000.

Company D. Cross-sectional 401(k) savings data from December 31 of 1998 and 1999 for all 401(k) plan participants (employee and non-employee), and from December 31, 2000 for all active employees (both 401(k) participants and non-participants) and non-employee 401(k) plan participants.

Company E. 1) Cross-sectional 401(k) savings data from December 31 of 1998, 1999 and 2000 for all active employees (both 401(k) participants and non-participants) and nonemployee 401(k) plan participants; 2) Longitudinal 401(k) savings data from March, 1996 through March, 2000.

Company F. Cross-sectional 401(k) savings data from December 31 of 1998, 1999 and 2000 for all active employees (both 401(k) participants and non-participants) and non-employee 401(k) plan participants.

Company G. Cross-sectional 401(k) savings data from December 31, 1999 for all active employees (both 401(k) participants and non-participants) and non-employee 401(k) plan participants.

The cross-sectional data available for these various companies include basic demographic information (age, hire date, gender, income), as well as point-in-time information on 401(k) saving such as participation status, contribution rate, account balances, and asset allocation.

The longitudinal data includes daily information on the 401(k) contribution rate, account balances, and asset allocation of $401(\mathrm{k})$ plan participants. It does not include demographic information or information on non-participating employees. 


\section{Section I}

\section{Which of the following statements describes your current participation in the XXX} Company, Inc. 401(k) Plan?

$\square$ I am currently contributing to the plan

$\square$ I am not currently contributing to the plan, but I have previously contributed to the plan

$\square$ I am not currently contributing to the plan, and I have never contributed to the plan

2. For each of the following questions, please indicate how strongly you agree or disagree with respect to the XXX Company, Inc. 401(k) plan. To indicate your level of agreement, please use the following scale (if you have no experience with a given item, please respond with "have no opinion").

Strongly agree

Somewhat agree

Neither agree nor disagree

Somewhat disagree

Strongly disagree

Have no opinion

a. I have a good understanding of the 401(k) savings plan overall

b. I have a good understanding of the 401(k) savings plan investment fund choices

c. I think the $401(\mathrm{k})$ plan meets my needs

d. The XXX Company, Inc. 401(k) plan is better than plans offered by other companies

3. For each of the following questions, please indicate how satisfied you are with that aspect of the XXX Company, Inc. 401(k) plan. To indicate your level of satisfaction, please use the following scale (if you have no experience with a given item, please respond with "have no opinion").

Very satisfied

Somewhat satisfied

Neither satisfied nor dissatisfied

Somewhat dissatisfied

Very dissatisfied

Have no opinion 

a. Convenience of payroll deductions for savings
b. Number of investment options
c. Variety of investment options
d. Account Statements
e. Internet access to your $401(\mathrm{k})$ plan
f. Loans

Please use the space provided to fill in your response to the following question:

4. What, if anything, could your company do differently in terms of the XXX Company, Inc. 401(k) plan that would increase your satisfaction level, relating to any of the items listed above?

\section{Section II}

Please check the appropriate box for each of the following questions:

\section{How would you describe yourself as an Internet user?}

Very experienced

Somewhat experienced

Not too experienced

Not at all experienced

\section{Do you have access to the Internet at home?}

Yes

$\square$ No

\section{How would you describe your level of financial knowledge?}

Very knowledgeable

Somewhat knowledgeable

Not too knowledgeable

Not at all knowledgeable 
8. Which of the following best describes your job?

Management

Other salaried position

Hourly

Other

9. Which of the following best describes your level of education?

High school or less

Some college

College graduate

Graduate school

\section{Section III}

These next few questions discuss retirement savings. Please check the appropriate box(es) for each of the following questions, and/or fill in the blanks, as appropriate:

10. First, based on anything you may have heard or read, what percent of your income do you think you should ideally be saving for retirement?

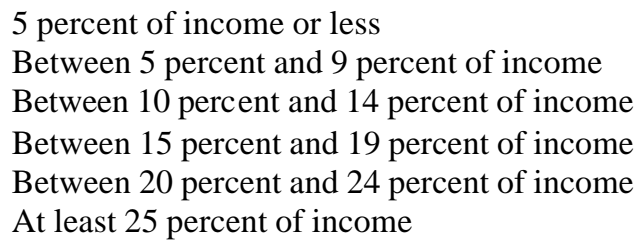

11. Think about how much you are actually currently saving for retirement. Compare your actual saving rate to your ideal saving rate. Right now, your actual retirement saving rate is:

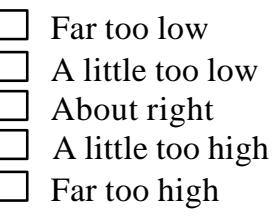

IF YOU ARE CURRENTLY CONTRIBUTING TO YOUR COMPANY 401(K) PLAN, PLEASE ANSWER QUESTIONS 12 THROUGH 17.

IF YOU ARE NOT CURRENTLY CONTRIBUTING TO YOUR COMPANY 401(K) PLAN, PLEASE SKIP TO QUESTION 18. 
12. Are you contributing currently at the maximum $401(\mathrm{k})$ savings rate?

Yes

No

13. Which one of the following statements best describes your 401(k) contribution plans over the next few months?

I plan to raise my contribution rate.

I plan to lower my contribution rate.

I don't plan to make any changes.

IF YOU ARE NOT PLANNING TO MAKE ANY CONTRIBUTION CHANGES, PLEASE SKIP TO QUESTION 15.

14. What percent of your salary are you planning to contribute?

15. Which one of the following statements best describes your $401(\mathrm{k})$ fund allocation plans over the next few months?

I am considering selecting different funds.

I am considering rebalancing among the funds I currently have.

$\square$ I am not planning to make any changes in regard to my fund allocations.

I am considering both selecting different funds and rebalancing among the funds I currently have

16. When do you next plan to make changes in your $401(\mathrm{k})$ plan?

In the next few days

In the next week

In the next two weeks

In the next three weeks

Sometime in the next month

Sometime in the next two months

Other:

17. What company resources will you use to make changes to your $401(\mathrm{k})$ plan? Check all that apply.

Speak to benefit center representative or use phone-based "Benefits Express"

Use the 401(k) web site: Your Benefits Resources (including advice and education resources, e.g., mPower and 401Kafe)

Consult the new hire kit (given to all new employees)

Other: Please specify: 
IF YOU ARE CURRENTLY CONTRIBUTING TO YOUR COMPANY 401(K) PLAN, PLEASE SKIP TO QUESTION 21.

\section{IF YOU ARE NOT CURRENTLY CONTRIBUTING TO YOUR COMPANY 401(K) PLAN, PLEASE ANSWER QUESTIONS 18 TO 20.}

18. When you enroll/re -enroll in the XXX Company, Inc. 401(k) plan, what percent of your salary do you expect to contribute to the plan?

Between 0 percent and 3 percent of income

Between 4 percent and 6 percent of income

Between 7 percent and 9 percent of income

Between 10 percent and 12 percent of income

Between 13 percent and 15 percent of income

19. When do you plan to enroll/re-enroll in the 401(k) plan?

In the next few days

In the next week

In the next two weeks

In the next three weeks

Sometime in the next month

Sometime in the next two months

Other:

20. What company resources will you use to enroll in the 401(k) plan? Check all that apply.

Speak to benefits center representative

Use the 401(k) web site

Consult the new hire kit (given to all new employees)

Other. Please specify:

Thank you for your participation in this survey.

For more information on the XXX Company, Inc. 401(k) plan, click here: URL. 


\section{References}

Andrews, Emily S. (1992), "The Growth and Distribution of 401(k) Plans," in John Turner and Daniel Beller, eds. Trends in Pensions 1992 (Washington, DC.: U.S. Department of Labor, Pension and Welfare Benefits Administration), 149-176.

Bassett, William F., Michael J. Fleming, and Anthony P. Rodrigues (1998), "How Workers Use 401(k) Plans?: The Participation, Contribution, and Withdrawal Decisions," National Tax Journal, 51 (2): 263-289.

Bayer, Patrick J., B. Douglas Bernheim, and J. Karl Scholz (1996), "The Effects of Financial Education in the Workplace: Evidence from a Survey of Employers," NBER Working Paper No. 5655.

Benartzi, Shlomo (2001), "Excessive Extrapolation and the Allocation of 401(k) Accounts to Company Stock," Journal of Finance, 56 (5), 1747-1764.

Benartzi, Shlomo and Richard Thaler (2001a), "Naive Diversification Strategies in Defined Contribution Savings Plans," American Economic Review, 91 (1): 79 - 98.

Benartzi, Shlomo and Richard Thaler (2001b), "Save More Tomorrow: Using Behavioral Economics to Increase Employee Saving," University of California-Los Angeles Working Paper.

Benartzi, Shlomo and Richard Thaler (2001c), "How Much is Investor Autonomy Worth?" University of California-Los Angeles Working Paper.

Bernheim, B. Douglas (1995), "Do Households Appreciate Their Financial Vulnerabilities? An Analysis of Actions, Perceptions, and Public Policy," in Tax Policy for Economic Growth in the 1990s (Washington, D.C.: American Council for Capital Formation), 1-30.

Bernheim, B. Douglas and Daniel M. Garret (1996), "The Determinants and Consequences of Financial Education in the Workplace: Evidence from a Survey of Households," NBER Working Paper No 5667.

Bernheim, B. Douglas, Daniel M. Garrett and Dean M. Maki (1997), "Education and Saving: The Long-Term Effects of High School Financial Curriculum Mandates," NBER Working Paper No. 6085. Forthcoming Journal of Public Economics.

Bureau of Labor Statistics (1998), Employee Benefits in Medium and Large Private Establishments (Washington DC: U.S. Department of Labor, Bureau of Labor Statistics).

Choi, James, David Laibson, Brigitte Madrian, and Andrew Metrick, (2001), "For Better or for Worse: Default Effects and 401(k) Savings Behavior," University of Chicago Working Paper. 
DeVaney, Sharon A. et al. (1995), "Saving and Investing for Retirement: The Effect of a Financial Education Program," Family Economics and Resource Management Biennial, 153-158.

Diamond, Peter, and Botand Koszegi (2000), "Quasi-Hyperbolic Discounting and Retirement," Massachusetts Institute of Technology Department of Economics Working Paper Series, Working Paper 00-03.

Engen, Eric M., William G. Gale, and John Karl Scholz (1994), "Do Saving Incentives Work?," Brookings Papers on Economic Activity, 1994, 1, 85-180.

Engen, Eric M., William G. Gale and John Karl Scholz (1996), "The Illusory Effects of Saving Incentives on Saving," Journal of Economic Perspectives, 10 (4): 113-138.

Even, William E., and David A. Macpherson (1997), "Factors Influencing Participation and Contribution Levels in 401(k) Plans," Florida State University Working Paper.

Farkas, Steve and Jean Johnson (1997), "Miles to Go: A Status Report on Americans' Plans for Retirement" (New York: Public Agenda).

Fidelity Investments (2001), Building Futures: A Report on Corporate Defined Contribution Plans, Volume II (Boston: Fidelity Investments).

Hewitt Associates (2001), Trends and Experience in 401(k) Plans (Lincolnshire, IL: Hewitt Associates).

Holden, Sarah, Jack VanDerHei, and Carol Quick (2000), "401(k) Plan Asset Allocation, Account Balances, and Loan Activity in 1998," Investment Company Institute Perspective 6 (1).

HR Focus (2000), "What is the Value of Financial Education Workshops?," HR Focus, Febuary 2000 , p. 15.

Internal Revenue Service (1998), Internal Revenue Bulletin 98-25 (June 22, 1998), p. 8. Downloaded from http://ftp.fedworld.gov/pub/irs-irbs/irb98-25.pdf.

Internal Revenue Service (2000a), Internal Revenue Bulletin 2000-7 (February 14, 2000), p. 617. Downloaded from http://ftp.fedworld.gov/pub/irs-irbs/irb00-7.pdf.

Internal Revenue Service (2000b), Internal Revenue Bulletin 2000-31 (July 31, 2000), pp. 138142. Downloaded from http://ftp.fedworld.gov/pub/irs-irbs/irb00-31.pdf.

Investment Company Institute, 2000, 401(k) Plan Participants: Characteristics, Contributions, and Account Activity, (Washington, DC: Investment Company Institute).

Jacobius, Arleen (2000), “Top-notch Education Campaigns Honored," Pensions \& Investments 28 (3): 29. 
Kahneman, Daniel and Amos Tversky (1974), "Judgment under uncertainty: Heuristics and biases," Science, 185: 1124-1131.

Kratzer, Constance Y. et al. (1998), "Financial Education in the Workplace: Results of a Research Study,” Journal of Compenstion and Benefits, 14 (3): 24-27.

Kusko, Andrea, James Poterba and David Wilcox (1998), "Employee Decisions with Respect to 401(k) Plans," in Olivia Mitchell and Sylvester Schieber, eds., Living with Defined Contribution Pensions: Remaking Responsibility for Retirement (Philadelphia: University of Pennsylvania Press), 98-112.

Laibson, David I., Andrea Repetto, and Jeremy Tobacman (1998), "Self-Control and Saving for Retirement," Brookings Papers on Economic Activity, 1998, 1, 91-196.

Madrian, Brigitte C. and Dennis F. Shea (2001a), "The Power of Suggestion: Inertia in 401(k) Participation and Savings Behavior," Quarterly Journal of Economics.

Madrian, Brigitte C. and Dennis F. Shea (2001b), "Preaching to the Converted and Converting Those Taught: Financial Education in the Workplace," University of Chicago Working Paper.

McCarthy, Mike and Liz McWhirter (2000), “Are Employees Missing the Big Picture? Study Shows Need for Ongoing Financial Education,” Benefits Quarterly, 16 (1): 25-31.

Milne, Deborah, Jack Vanderhei and Paul Yakoboski (1995), "Can We Save Enough to Retire? Participant Education in Defined Contribution Plans," EBRI Issue Brief No. 160 (Washington, DC: Employee Benefit Research Institute).

Milne, Deborah, Jack Vanderhei and Paul Yakoboski (1996), "Participant Education: Actions and Outcomes," EBRI Issue Brief No. 169 (Washington, DC: Employee Benefit Research Institute).

Murray, M. Christian (1999), “401(k) Plan Sponsors Find Education Pays,” National Underwriter, 103 (19): 36-38.

O'Donoghue, Ted, and Matthew Rabin (1998), "Procrastination in Preparing for Retirement," University of California-Berkeley Working Paper.

Papke, Leslie E. (1995), "Participation in and Contributions to 401(k) Pension Plans," Journal of Human Resources, 30 (2): 311-325.

Papke, Leslie E. and James M. Poterba (1995), "Survey Evidence on Employer Match Rates and Employee Saving Behavior in 401(k) Plans," Economics Letters 49 (3): 313-17.

Pensions and Investments (2001), "Lucent's 401 and (k) Crash,” September 3rd, p. 10. 
Poterba, James M., Steven F. Venti, and David A. Wise (1996), "How Retirement Saving Programs Increase Saving," Journal of Economic Perspectives, 10 (4): 91-112.

Poterba, James M. Steven F. Venti and David A. Wise (1998a), "Lump Sum Distributions from Retirement Savings Plans: Receipt and Utilization," in David A. Wise, ed., Inquiries in the Economics of Aging (Chicago: University of Chicago Press), 85-105.

Poterba, James M., Steven F. Venti, and David A. Wise (1998b), "Personal Retirement Saving Programs and Asset Accumulation," in David Wise, ed., Frontiers in the Economics of Aging, (Chicago: University of Chicago Press), 23-124.

Profit Sharing/401(k) Council of America (2001), “Automatic Enrollment 2001: A Study of Automatic Enrollment Practices in 401(k) Plans." Downloaded from http://www.pcsa.org/data/autoenroll2001.asp on April 19, 2001.

Vanguard Center for Retirement Research (2001), "Automatic Enrollment: Vanguard Client Experience." Downloaded from http://institutional.vanguard.com/pdf/automatic enrollment clientexp.pdf on September 6, 2001.

Watson Wyatt Worldwide (2001), "Retirement Plan Provisions: What, When and How Much? Economic Growth and Tax Relief Reconciliation Act of 2001.” Downloaded from http://www.watsonwyatt.com/homepage/services/retirement/resrender.asp?id=W-471\&page $=1$ on November 5, 2001. 
TABLE 1. Companies and Their 401(k) Plan Changes or Other Interventions

\begin{tabular}{|c|c|c|c|c|}
\hline Company & Industry & $\operatorname{Size}^{\mathrm{a}}$ & $\begin{array}{l}\text { Plan Change/ } \\
\text { Intervention }\end{array}$ & $\begin{array}{l}\text { Date of Change/ } \\
\text { Intervention }\end{array}$ \\
\hline $\mathrm{A}$ & Food & 10,000 & Savings survey & January 2001 \\
\hline B & Office equipment & 30,000 & Automatic enrollment & January 1997 \\
\hline \multirow[t]{2}{*}{$\mathrm{C}$} & Insurance & 30,000 & Automatic enrollment & April 1998 \\
\hline & & & Financial education seminars & January-December 2000 \\
\hline $\mathrm{D}$ & Food & 20,000 & Automatic enrollment & January 1998 \\
\hline $\mathrm{E}$ & Utility & 10,000 & Increased match threshold & January 1997 \\
\hline \multirow[t]{2}{*}{$\mathrm{F}$} & Consumer packaged goods & 40,000 & Change eligibility & July 1998 \\
\hline & & & Instituted employer match & October 2000 \\
\hline $\mathrm{G}$ & Insurance & 50,000 & Change eligibility & January 1997 \\
\hline
\end{tabular}


TABLE 2: Self-reported Retirement Savings Adequacy and the Distribution of Actual 401(k) Contribution Rates (Company A)

Distribution of 401(k) Contribution Rates as a Fraction of Income

\begin{tabular}{|c|c|c|c|}
\hline & \multicolumn{3}{|c|}{ as a Fraction or meome } \\
\hline & $0 \%-4 \%$ & $5 \%-8 \%$ & $9 \%-12 \%$ \\
\hline $\begin{array}{l}\text { Respondents who describe their } \\
\text { avings rate as "too low" }\end{array}$ & $36 \%$ & $36 \%$ & $27 \%$ \\
\hline $\begin{array}{l}\text { Respondents who describe their } \\
\text { avings rate as "about right" }\end{array}$ & $12 \%$ & $15 \%$ & $73 \%$ \\
\hline
\end{tabular}


TABLE 3. 401(k) Participation by Tenure Before and After Automatic Enrollment

$$
\text { Company B }
$$

Company C

Company D

\begin{tabular}{|c|c|c|c|c|c|c|c|c|c|}
\hline & \multicolumn{2}{|c|}{ Hire date } & \multirow[b]{2}{*}{$\begin{array}{l}\text { After - } \\
\text { Before }\end{array}$} & \multicolumn{2}{|c|}{ Hire date } & \multirow[b]{2}{*}{$\begin{array}{l}\text { After - } \\
\text { Before }\end{array}$} & \multicolumn{2}{|c|}{ Hire date } & \multirow[b]{2}{*}{$\begin{array}{l}\text { After - } \\
\text { Before }\end{array}$} \\
\hline & Before AE & After AE & & Before AE & After AE & & Before AE & After AE & \\
\hline \multicolumn{10}{|l|}{ Tenure } \\
\hline 6 months & $26.4 \%$ & $93.4 \%$ & $67.0 \%$ & $35.7 \%$ & $85.9 \%$ & $50.2 \%$ & $42.5 \%$ & $96.0 \%$ & $53.5 \%$ \\
\hline 12 months & 37.8 & 95.7 & 57.9 & 40.2 & 85.3 & 45.1 & 49.6 & 96.6 & 47.0 \\
\hline 18 months & 47.7 & 97.0 & 49.3 & 44.3 & 86.0 & 41.7 & 56.6 & 97.2 & 40.6 \\
\hline 24 months & 54.1 & 97.6 & 43.5 & 49.8 & 85.7 & 35.9 & 61.7 & 99.1 & 37.4 \\
\hline 30 months & 60.0 & 97.7 & 37.7 & -- & -- & -- & 65.6 & 98.8 & 33.3 \\
\hline 36 months & 64.7 & 98.8 & 34.1 & -- & -- & -- & 69.0 & 100.0 & 31.0 \\
\hline
\end{tabular}

The sample for Companies $\mathrm{C}$ and D is all 401(k)-eligible employees. The sample for Company E is 401(k)-eligible employees aged 40+ at the time of hire. For Company E, the data in the "Before AE" column includes only employees not yet subject to automatic enrollment when it was applied to previously hired nonparticipants. For Companies B and D, the first two columns of numbers give the fraction of employees who have ever participated in the 401(k) plan. For Company C, the first two columns give the fraction of employees contemporaneously participating in the 401(k) plan. 
TABLE 4. Fraction of 401(k) Participants at the Automatic Enrollment Default Company B $\quad$ Company C Company D

\begin{tabular}{lccc}
\hline Tenure & & & \\
6 months & $67.2 \%$ & $72.6 \%$ & $54.5 \%$ \\
12 months & 61.2 & 59.3 & 50.9 \\
18 months & 61.4 & 47.6 & 43.7 \\
24 months & 51.4 & 39.6 & 39.5 \\
30 months & 53.9 & -- & 39.4 \\
36 months & 43.6 & -- & 48.2 \\
\hline $\begin{array}{l}\text { The sample for Companies B and C is 401(k) participants hired after automatic enrollment. The sample } \\
\text { for Comp any D is further restricted to participants aged 40+ at the time of hire. }\end{array}$ \\
\hline
\end{tabular}


TABLE 5. Employer Matching and 401(k) Participation

\begin{tabular}{lcc}
\hline $\begin{array}{l}\text { Independent } \\
\text { Variable }\end{array}$ & $\begin{array}{c}\text { Company E } \\
\text { (Hazard ratio) }\end{array}$ & $\begin{array}{c}\text { Company F } \\
\text { (Hazard ratio) }\end{array}$ \\
\hline Female & 0.8964 & 1.0237 \\
& $(-1.21)$ & $(0.45)$ \\
Age & $1.1376^{* *}$ & $1.1480^{* *}$ \\
& $(3.54)$ & $(6.58)$ \\
Age $^{2}$ & $0.9985^{* *}$ & $0.9984^{* *}$ \\
& $(-3.25)$ & $(-5.88)$ \\
Threshold change & 0.7976 & -- \\
& $(-1.69)$ & $1.4642^{* *}$ \\
Match introduction & -- & $(6.84)$
\end{tabular}

Coefficients estimated from a Cox proportional hazard model of 401(k) participation with time-varying covariates. For Company E, the sample is employees hired during 1996 or 1997 and still employed at year-end 1998, 1999 or 2000. For Company F, the sample is employees hired on or after January 1, 1998 and still employed at year-end 1998, 1999 or 2000. In Company E, the variable Threshold change is a dummy variable that equals 1 after the match threshold was raised in Company G (on January 1 , 1997). In Company F, Match introduction is a dummy variable that equals 1 after the company match was announced to employees (on July 1,2000). The reported coefficients are hazard ratios, with corresponding z-statistics in parentheses. $* *$ indicates that the coefficient is significantly different from unity at the 1 percent level. 
TABLE 6. Financial Education and Actual vs. Planned Savings Changes (Company C)

\begin{tabular}{lccc}
\hline \multirow{2}{*}{ Planned Action } & \multicolumn{2}{c}{ Seminar Attendees } & Non-Attendees \\
\cline { 2 - 3 } & Planned Change & Actual Change & Actual Change \\
\hline Non-participants & & & \\
Enroll in 401(k) plan & $100 \%$ & $14 \%$ & $7 \%$ \\
$\mathbf{4 0 1 ( k )}$ participants & & $5 \%$ & $5 \%$ \\
$\begin{array}{l}\text { Increase contribution rate } \\
\text { Change fund selection }\end{array}$ & $28 \%$ & $15 \%$ & $10 \%$ \\
Change fund allocation & $47 \%$ & $10 \%$ & $6 \%$ \\
\hline $\begin{array}{l}\text { The sample is active 401(k)-eligible employees at company locations that offered financial education } \\
\text { seminars from January-June 2000. Actual changes in savings behavior are measured over the period } \\
\text { from December 31, 1999 through June 30, 2000. Planned changes are those reported by seminar }\end{array}$ \\
attendees in an evaluation of the financial education seminars at the conclusion of the seminar. The \\
planned changes from surveys responses of attendees have been scaled to reflect the 401(k) participation \\
rate of seminar attendees.
\end{tabular}


Figure 1.

The Distribution of Contribution Rates of 401 (k) Participants Hired Before and After Automatic Enrollment

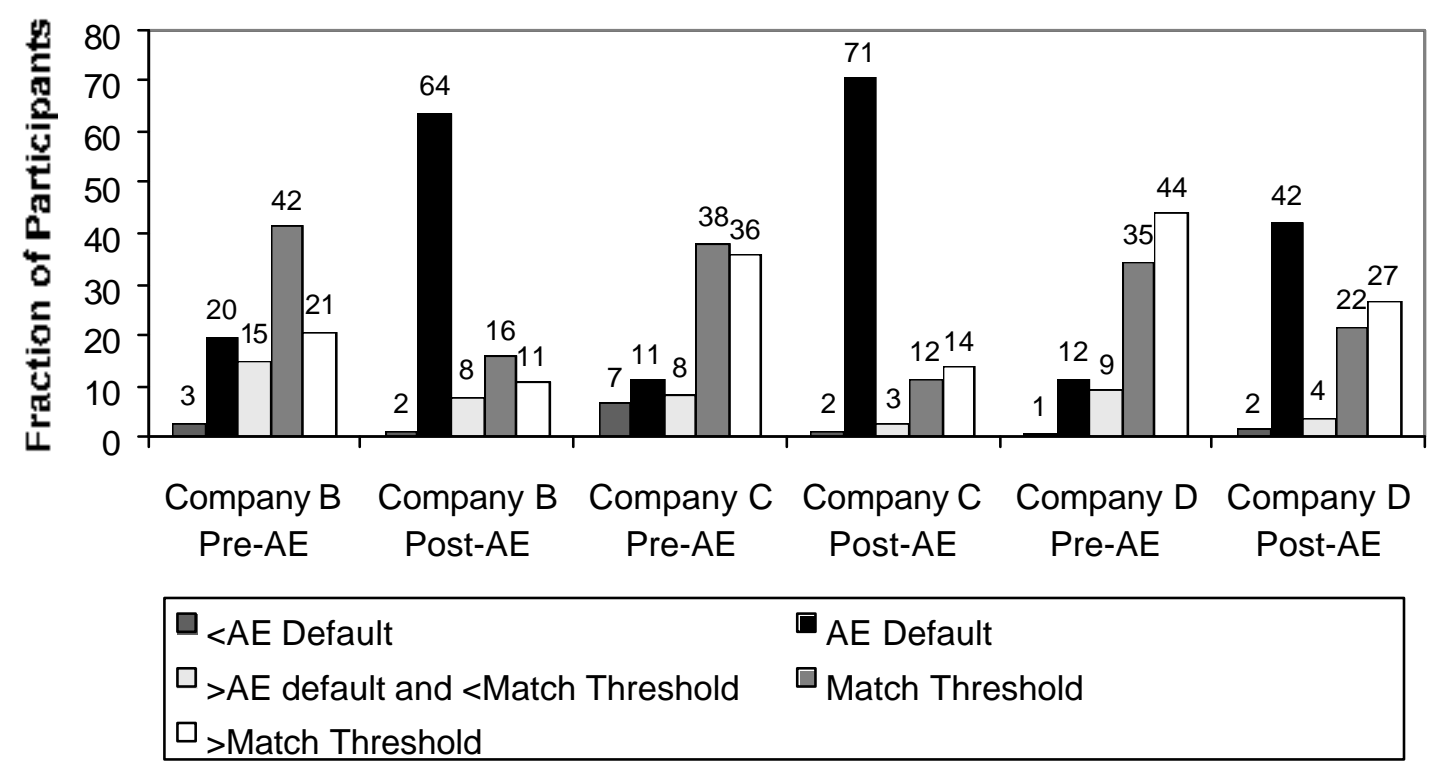


Figure 2.

\section{Asset Allocation of 401(k) Participants Hired \\ Before and After Automatic Enrollment}

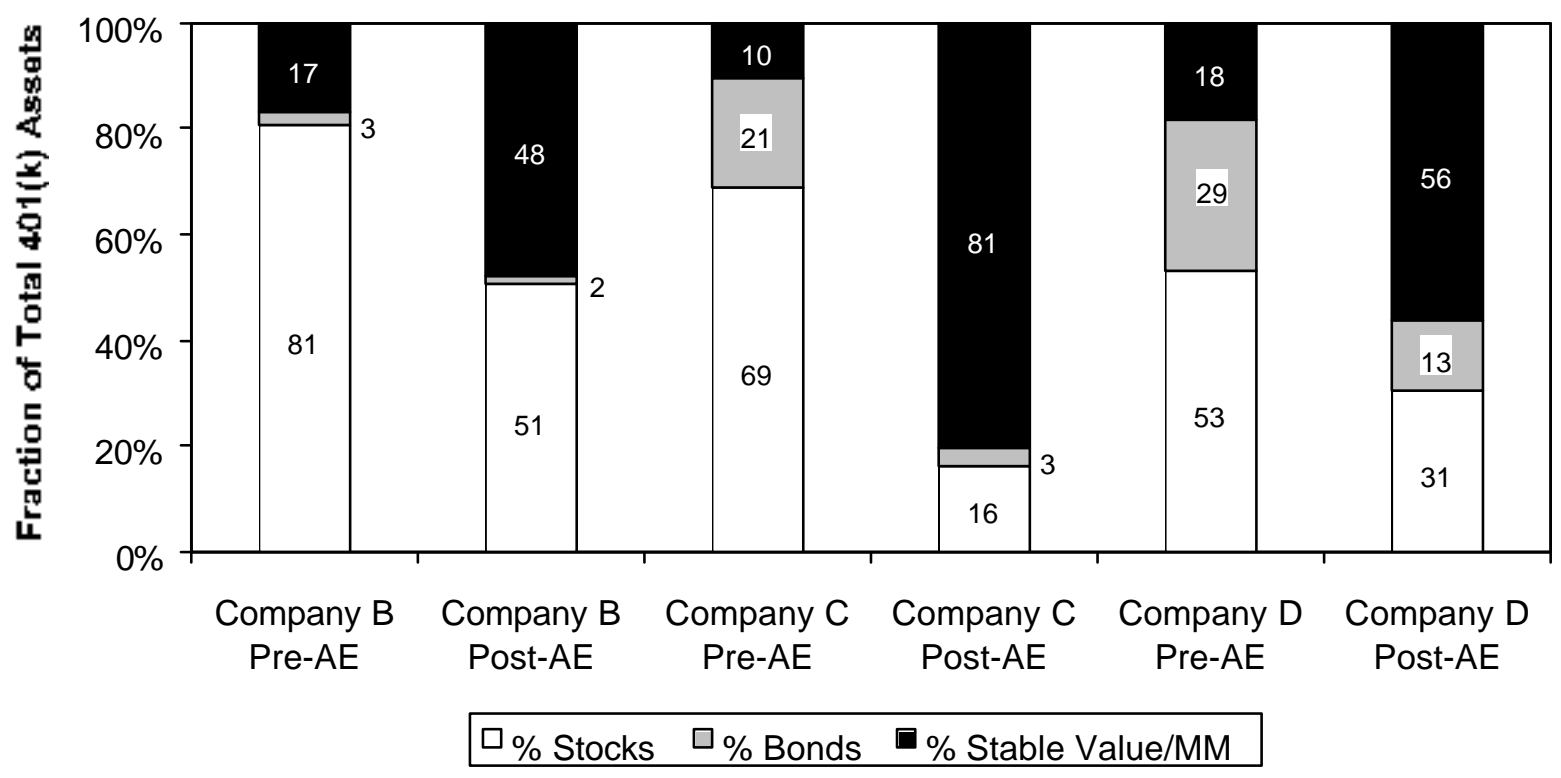


Figure 3A.

Balance Size and the Likelihood of a 401(k) Distribution for Terminated Employees (Company B)

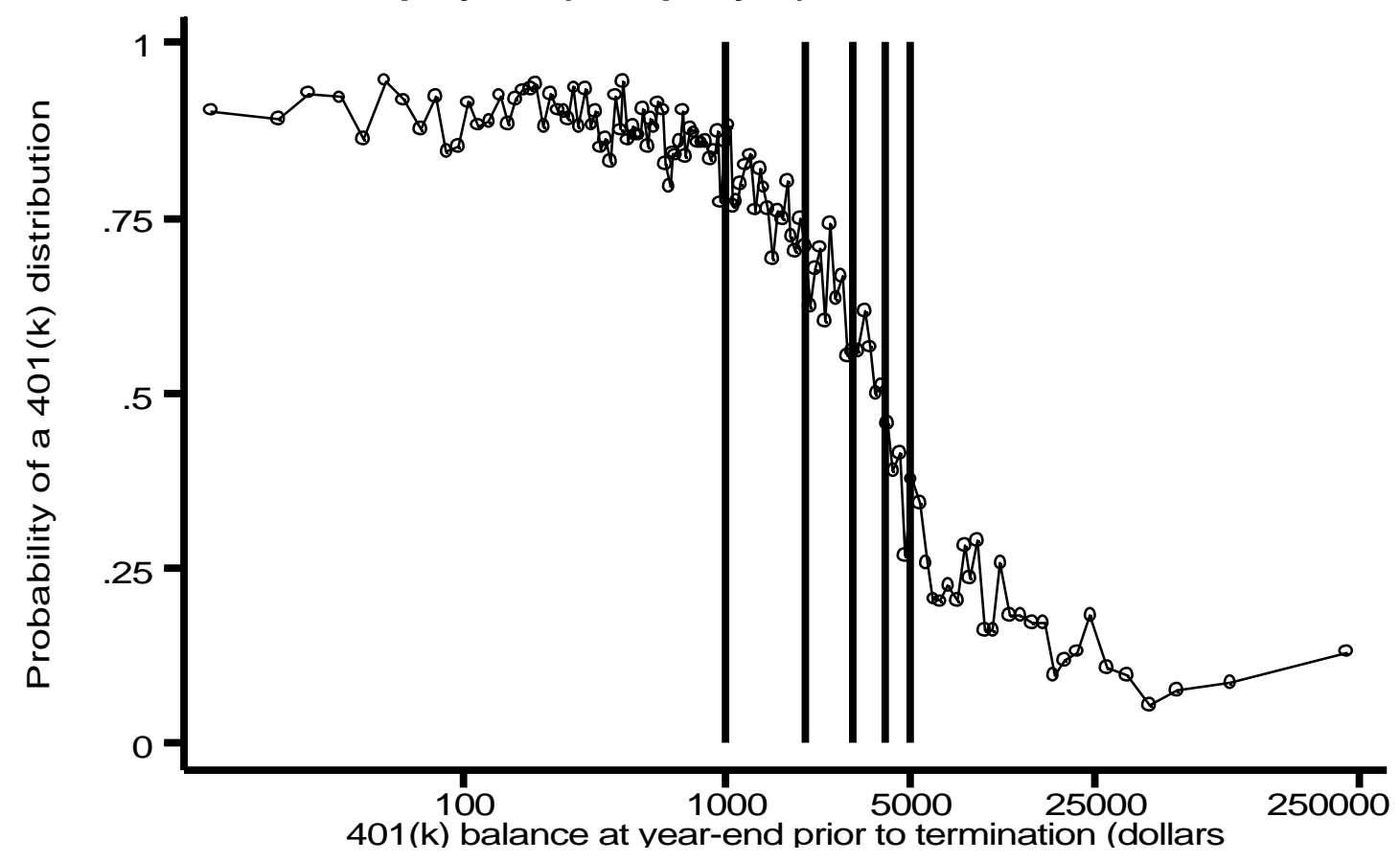

Figure 3B.

Balance Size and the Likelihood of a 401(k) Distribution for Terminated Employees (Company D)

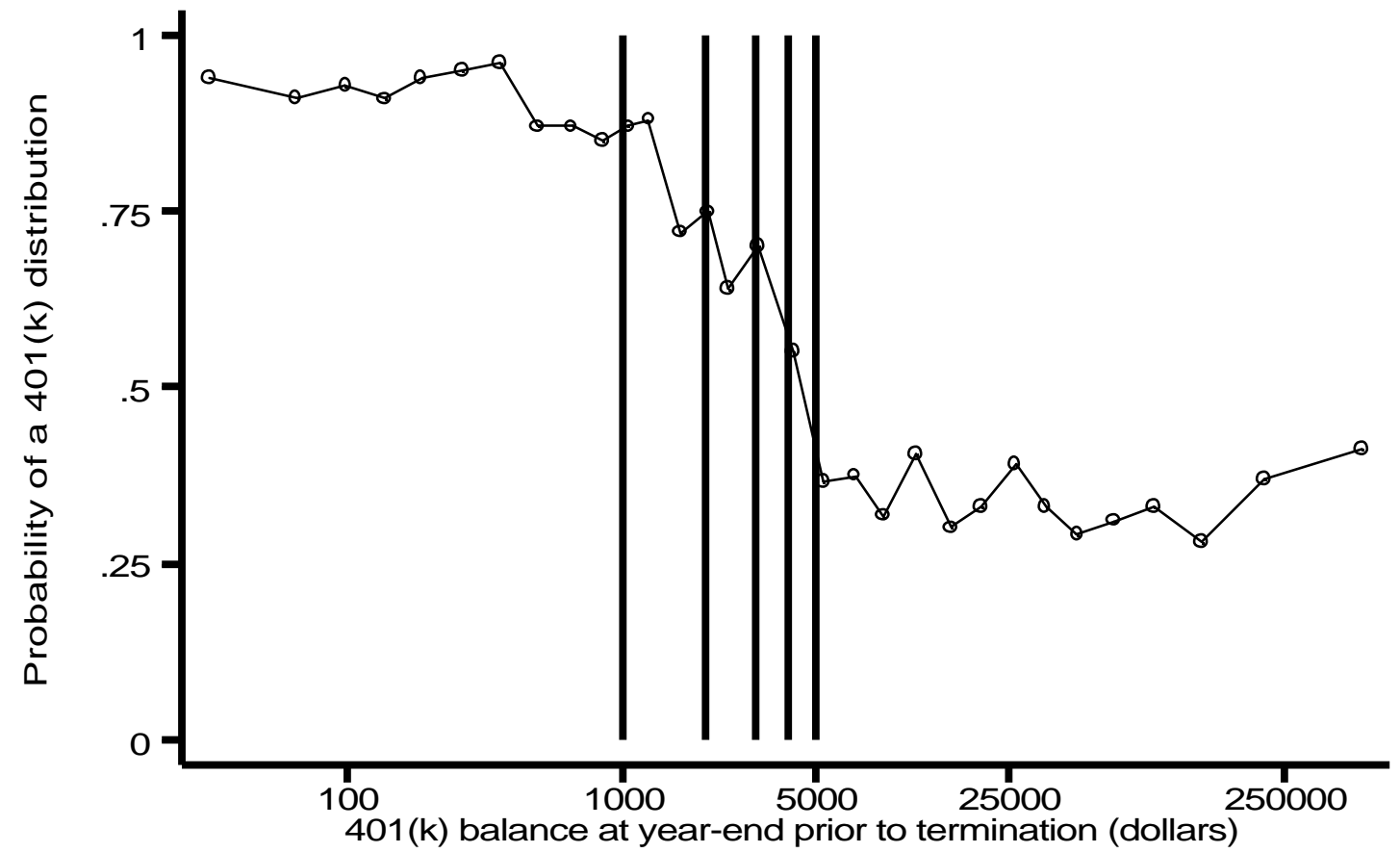


Figure 4.

The Evolution of the 401(k) Contribution Rate Distribution Over Time (Company E)

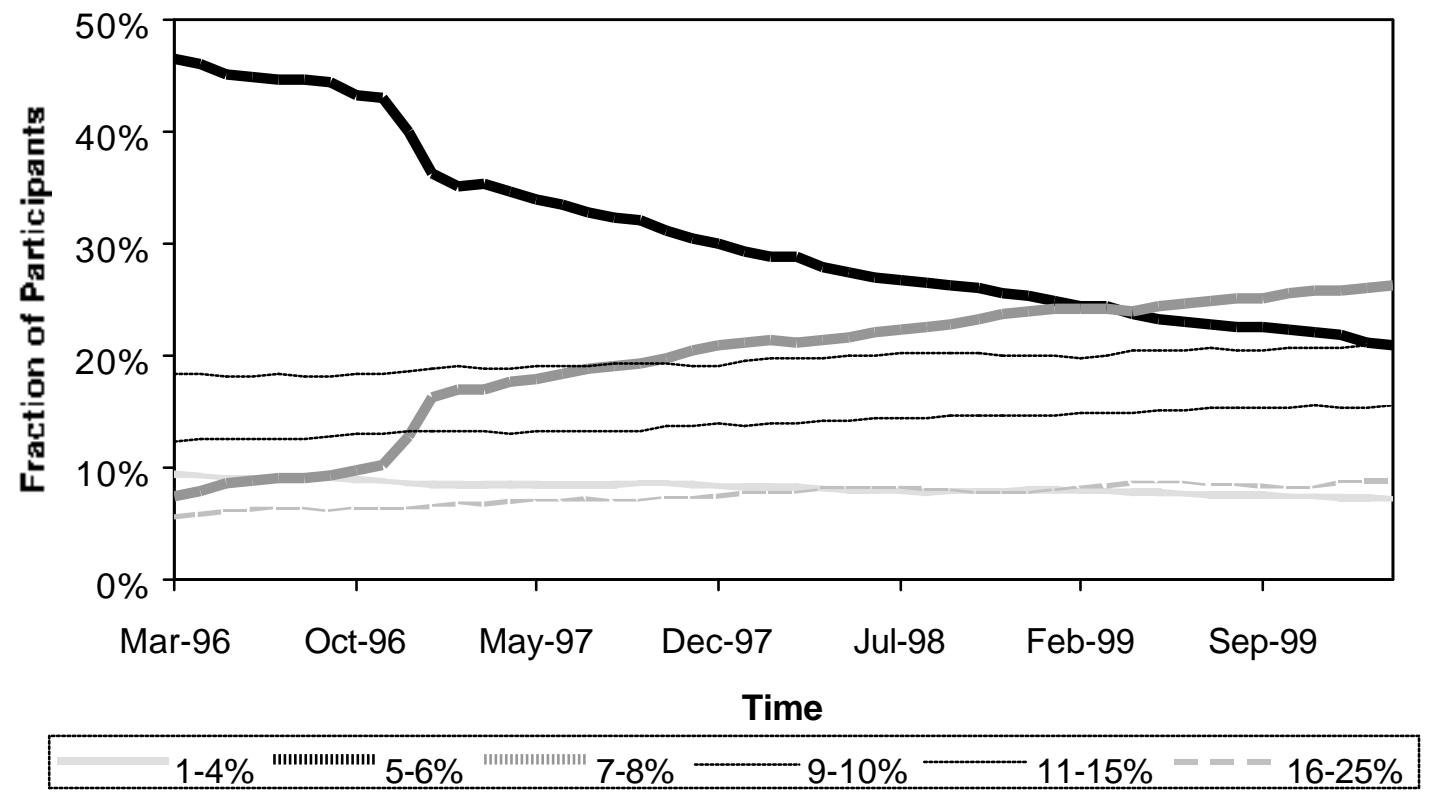


Figure 5.

\section{Employer Matching and 401(k) Participation (Company F)}

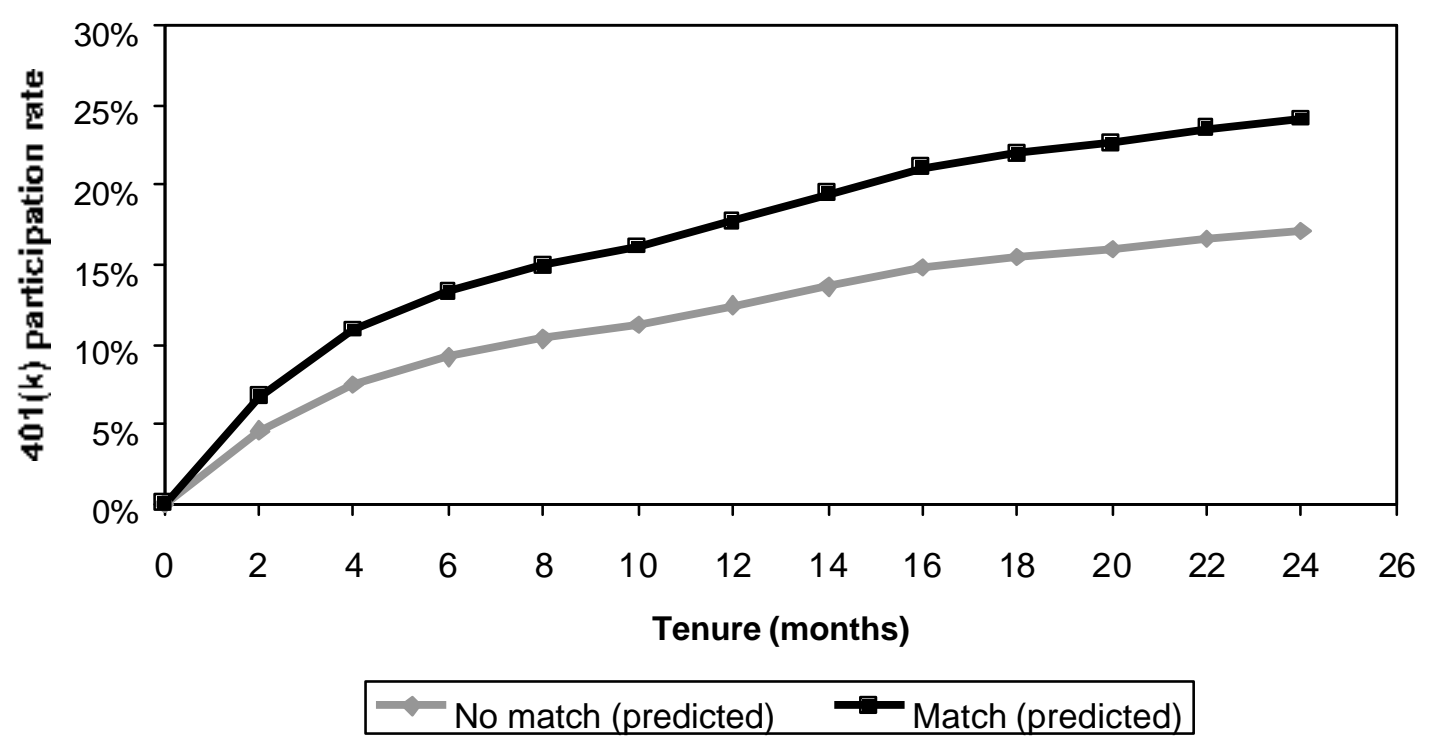


Figure 6.

\section{Employer Matching and the Distribution of 401(k) Contribution Rates (Company F)}

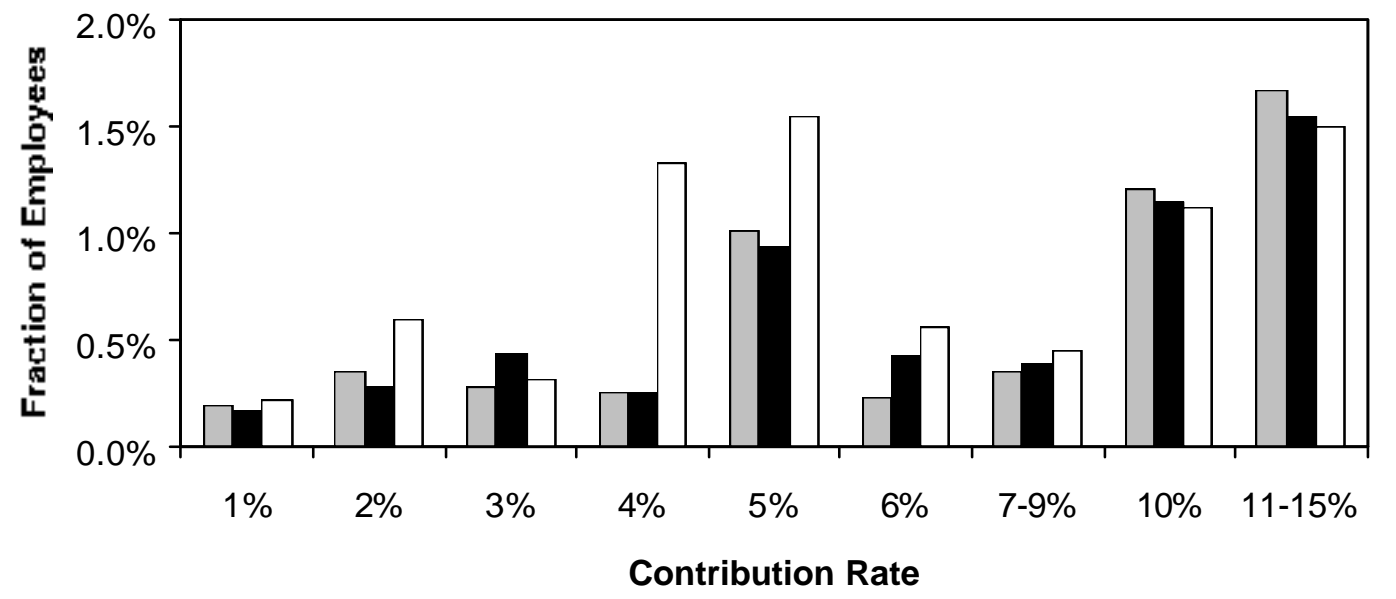

$\square$ Hired Jul-Dec 1998, 12/31/98 rate $\square$ Hired Jul-Dec 1999, 12/31/99 rate
$\square$ Hired Jul-Dec 2000, 12/31/00 rate 
Figure 7A.

Waiting Periods and 401(k) Participation

(Company F)

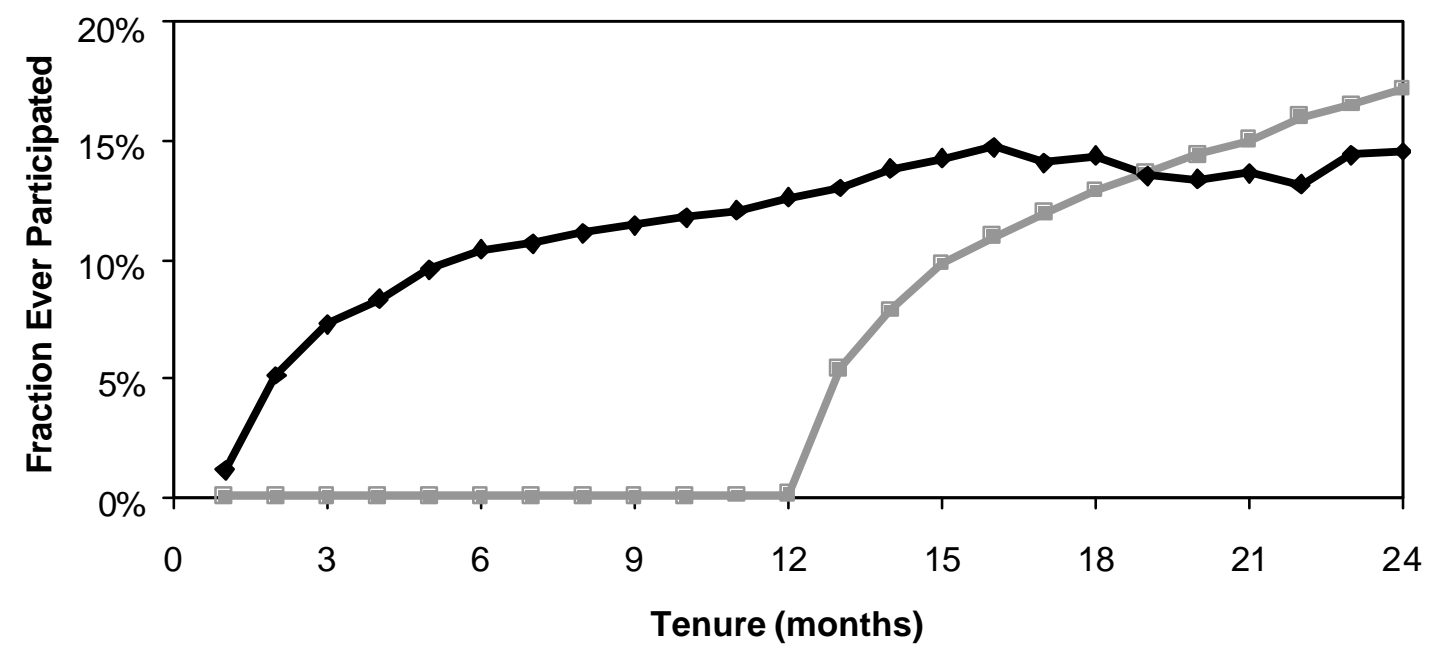

$\rightarrow$ Eligible after 1 year $\rightarrow$ Eligible immediately

Figure 7B.

Waiting Periods and 401(k) Participation

(Company G)

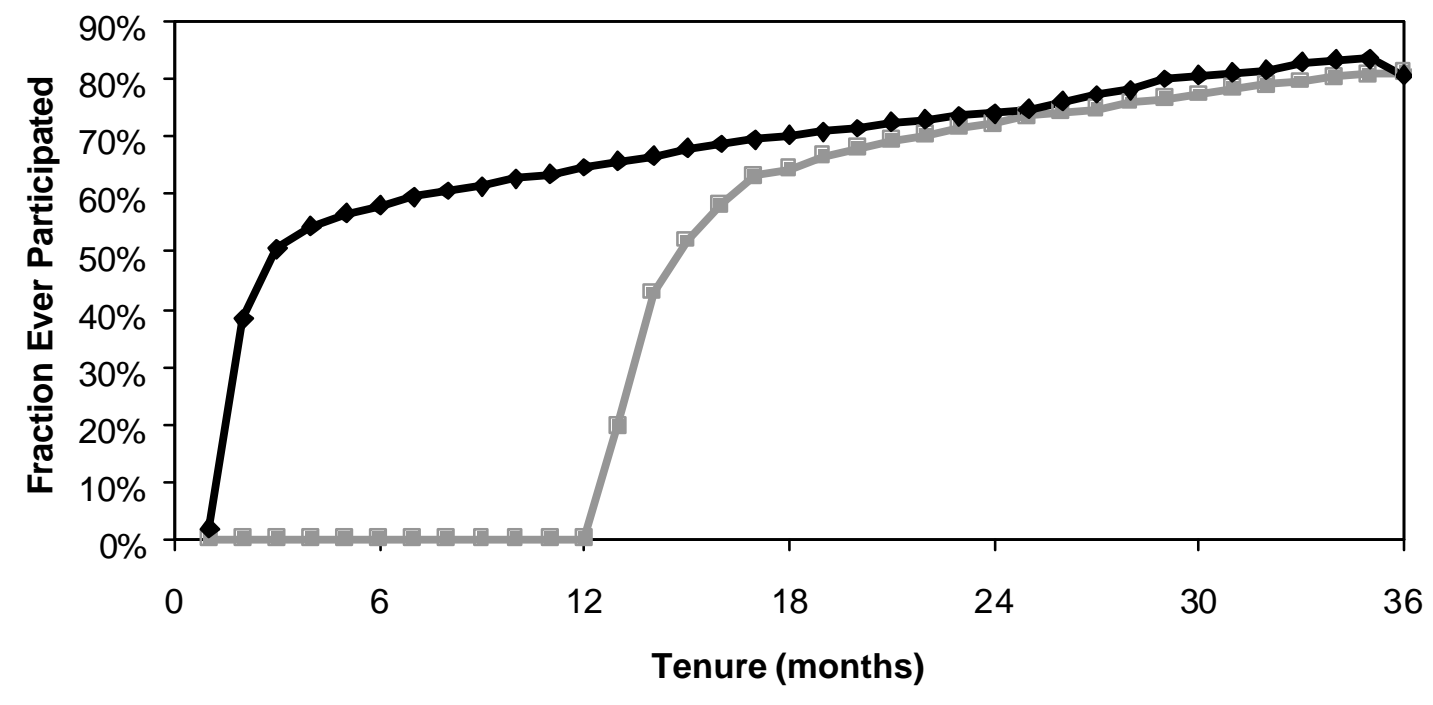

$\rightarrow$ Eligible after 1 year $\rightarrow$ Eligible immediately 